\title{
Calcium Signaling in Smooth Muscle
}

\author{
David C. Hill-Eubanks ${ }^{1}$, Matthias E. Werner ${ }^{2}$, Thomas J. Heppner ${ }^{1}$, and Mark T. Nelson ${ }^{1,2}$ \\ ${ }^{1}$ Department of Pharmacology, College of Medicine, University of Vermont, Burlington, Vermont 05405 \\ ${ }^{2}$ Cardiovascular Medicine, Faculty of Medical and Human Sciences, University of Manchester, Manchester \\ M13 9NT, United Kingdom
}

Correspondence: Mark.Nelson@uvm.edu

\begin{abstract}
Changes in intracellular $\mathrm{Ca}^{2+}$ are central to the function of smooth muscle, which lines the walls of all hollow organs. These changes take a variety of forms, from sustained, cell-wide increases to temporally varying, localized changes. The nature of the $\mathrm{Ca}^{2+}$ signal is a reflection of the source of $\mathrm{Ca}^{2+}$ (extracellular or intracellular) and the molecular entity responsible for generating it. Depending on the specific channel involved and the detection technology employed, extracellular $\mathrm{Ca}^{2+}$ entry may be detected optically as graded elevations in intracellular $\mathrm{Ca}^{2+}$, junctional $\mathrm{Ca}^{2+}$ transients, $\mathrm{Ca}^{2+}$ flashes, or $\mathrm{Ca}^{2+}$ sparklets, whereas release of $\mathrm{Ca}^{2+}$ from intracellular stores may manifest as $\mathrm{Ca}^{2+}$ sparks, $\mathrm{Ca}^{2+}$ puffs, or $\mathrm{Ca}^{2+}$ waves. These diverse $\mathrm{Ca}^{2+}$ signals collectively regulate a variety of functions. Some functions, such as contractility, are unique to smooth muscle; others are common to other excitable cells (e.g., modulation of membrane potential) and nonexcitable cells (e.g., regulation of gene expression).
\end{abstract}

\section{SMOOTH MUSCLE}

mooth muscle cells form a continuous layer $\checkmark$ that lines the walls of the hollow organs of the body, such as blood vessels, intestines, urinary bladder, airways, lymphatics, penis, and uterus. A defining feature of smooth muscle cells is their ability to contract. This property reflects the excitable nature of these cells, which allows for membrane potential-dependent influx of calcium $\left(\mathrm{Ca}^{2+}\right)$ and the $\mathrm{Ca}^{2+}$-dependent formation of cross-bridges between myosin and actin-the two major contractile proteins that drive contraction. The contractile property of smooth muscle plays an important functional role in these organs, notably by allowing dynamic changes in luminal volume. These changes may regulate the translational movement of the organ's contents, such as in the gastrointestinal tract, where the peristaltic action caused by sequential contraction of smooth muscle segments is responsible for the movement of food, and the urinary bladder, where smooth muscle in the wall relaxes during filling and contracts forcefully to expel urine during micturition. Uterine smooth muscle plays a similar role, relaxing during gestation to accommodate fetal growth and contracting vigorously during parturition. In the vasculature, the contractility of smooth muscle in the vessel wall is a primary determinant of blood pressure, which in turn controls blood flow and the distribution of nutrients and oxygen throughout the body.

Editors: Martin Bootman, Michael J. Berridge, James W. Putney, and H. Llewelyn Roderick

Additional Perspectives on Calcium Signaling available at www.cshperspectives.org

Copyright (C) 2011 Cold Spring Harbor Laboratory Press; all rights reserved; doi: 10.1101/cshperspect.a004549

Cite this article as Cold Spring Harb Perspect Biol 2011;3:a004549 
D.C. Hill-Eubanks et al.

\section{$\mathrm{Ca}^{2+}$ SIGNALS IN SMOOTH MUSCLE}

Smooth muscle contractility, and therefore hollow organ function, is regulated by changes in intracellular $\mathrm{Ca}^{2+}$ concentration $\left(\left[\mathrm{Ca}^{2+}\right]_{\mathrm{i}}\right)$. These changes may take a variety of forms, the simplest of which is a "global" (cell-wide) increase of the type associated with $\mathrm{Ca}^{2+}$-triggered actin-myosin cross-bridge formation and contraction. However, changes in intracellular $\mathrm{Ca}^{2+}$ may also be highly localized and often include a temporal component. Thus, $\mathrm{Ca}^{2+}$ changes may be sustained or transient, stationary or moving, or regularly repeating (Berridge 1997; Sanders 2001).

The nature of the $\mathrm{Ca}^{2+}$ signal depends to a large extent on the molecular mechanism responsible for generating it. Broadly speaking, there are two major mechanisms by which $\left[\mathrm{Ca}^{2+}\right]_{\mathrm{i}}$ is raised in smooth muscle: (1) entry of $\mathrm{Ca}^{2+}$ from the extracellular space, and (2) release of $\mathrm{Ca}^{2+}$ from intracellular stores. Influx of extracellular $\mathrm{Ca}^{2+}$ is mediated by ion channels in the plasmalemmal membrane, the most prominent of which is the voltagedependent $\mathrm{Ca}^{2+}$ channel (VDCC). Nonselective cation channels, such as transient receptor potential (TRP) channels and ionotropic purinergic (P2X) receptors, are also potentially important extracellular $\mathrm{Ca}^{2+}$ entry pathways in smooth muscle cells. Although a number of intracellular organelles take up and release $\mathrm{Ca}^{2+}$, the sarcoplasmic reticulum (SR) represents the largest pool of releasable $\mathrm{Ca}^{2+}$ in smooth muscle cells. In response to a variety of stimuli, $\mathrm{Ca}^{2+}$-release channels in the SR, namely ryanodine receptors $(\mathrm{RyR})$ and inositol trisphosphate receptors $\left(\mathrm{IP}_{3} \mathrm{Rs}\right)$, mediate efflux of $\mathrm{Ca}^{2+}$ from the SR into the cytoplasm of the cell.

\section{IMAGING INTRACELLULAR $\mathrm{Ca}^{2+}$}

Fluorescence, a property that allows certain molecules to absorb specific wavelengths of light and release energy in the form of light at a longer wavelength, has been exploited to produce numerous fluorescent indicators, including $\mathrm{Ca}^{2+}$-sensitive fluorescent dyes. The fluorescence properties of $\mathrm{Ca}^{2+}$-sensitive indicators change when $\mathrm{Ca}^{2+}$ is bound; thus, such dyes can be used to detect intracellular $\mathrm{Ca}^{2+}$ levels. Ion fluxes in smooth muscle can occur very rapidly-often in the millisecond range. This property has motivated the development of a number of very rapid fluorescent dyes that enable detection of such changes in ion concentrations with high temporal resolution.

Fluorescent dyes can be loaded into cells by microinjection, but are more commonly introduced by incubating isolated smooth muscle cells or intact tissue with the membranepermeant acetoxymethyl (AM) ester of the dye. The AM form is readily taken up by cells, but is acted on by intracellular esterases that cleave the ester bond to release the free anion, which is not membrane permeant and is thus retained within the cell. Most fluorescent $\mathrm{Ca}^{2+}$ indicators are based on fluorophore-conjugated derivatives of the $\mathrm{Ca}^{2+}$ chelator, BAPTA (bis- [oamino-phenoxy]-ethane- $N, N, N^{\prime} N^{\prime}$-tetraacetic acid), which is used for both ratiometric and nonratiometric $\mathrm{Ca}^{2+}$ applications (Tsien 1980). Ratiometric dyes are used to measure the intracellular concentration of $\mathrm{Ca}^{2+}$. These dyes show a shift in the excitation (e.g., Fura-2) or emission (e.g., indole-1) spectrum according to the concentration of free or unbound $\mathrm{Ca}^{2+}$. From the ratio of bound and unbound $\mathrm{Ca}^{2+}$, the free intracellular $\mathrm{Ca}^{2+}$ concentration can be determined. Nonratiometric dyes, such as those in the Fluo family, show an increase in fluorescence quantum yield or intensity on binding $\mathrm{Ca}^{2+}$ and are useful for detecting qualitative changes in $\mathrm{Ca}^{2+}$ levels. Although nonratiometric dyes are not usually used for quantitative $\mathrm{Ca}^{2+}$ measurements, methods have been developed to calculate $\mathrm{Ca}^{2+}$ concentrations using single-wavelength fluorescence signals (Jaggar et al. 1998a; Maravall et al. 2000). One advantage of ratiometric dyes is that the ratio normalizes fluorescence variations caused by uneven cell thickness, dye distribution, dye leakage, or photobleachingproblems that are common to nonratiometric dyes. A disadvantage of ratiometric dyes is that they require excitation in the UV range. Some parameters to consider when selecting a fluorescent dye include (1) ion specificity, 
(2) dissociation constant $\left(\mathrm{K}_{\mathrm{d}}\right)$, (3) hardware suitability (excitation and emission spectra), (4) fluorescence intensity, (5) availability as an AM ester, and (6) sensitivity to photobleaching. $\mathrm{Ca}^{2+}$ signals are typically imaged using laser-scanning confocal microsopes. In its simplest form, a confocal microscope system comprises three main components: (1) a light source; (2) optical and electronic components to manipulate, display, and analyze signals; and (3) a microscope. Lasers, coupled to either upright or inverted microscopes, are commonly used as the light source for confocal microscopes. Although gas lasers (e.g., Ar-ion, Krion, $\mathrm{HeNe}$ ) provide numerous lasing lines from UV to red, and are well suited for optimal excitation of fluorescent probes, solid-state lasers are increasingly being used because they offer the advantages of longer lifetime, lower power consumption, and compact size.

To record very rapid events or determine the kinetics of a $\mathrm{Ca}^{2+}$ event by confocal microscopy, researchers have typically measured $\mathrm{Ca}^{2+}$ fluxes using a line-scanning procedure. In linescan mode, a single line is repeatedly scanned across the cell for a period of time. Each line is then aligned to form an image that is a plot of fluorescence along the scanned line versus time (Fig. 1). Although line scans are still used, the development of very sensitive CCD (charge-coupled device) cameras and rapid
$\mathrm{Ca}^{2+}$-sensitive dyes allows laser-scanning confocal systems to routinely achieve detailed spatial and temporal resolution, which is crucial for determining the origin of a $\mathrm{Ca}^{2+}$ event.

Confocal microscopy systems can also be used to measure changes in cellular $\mathrm{Ca}^{2+}$ caused by activation of photoprotected ("caged") compounds. In this technique, the concentration of ions, signaling molecules, or other biologically active compounds can be instantaneously changed by UV stimulation of cells loaded with their caged equivalent. The resulting changes in intracellular $\mathrm{Ca}^{2+}$ can be monitored using the same system. By employing caged $\mathrm{Ca}^{2+}$ or $\mathrm{Ca}^{2+}$-releasing compounds (e.g., $\mathrm{IP}_{3}$ ), this approach can also be used to directly elevate $\mathrm{Ca}^{2+}$ within a cell. This uncaging strategy facilitates the study of a particular signaling step independent of preceding steps in the signaling pathway.

Specialized techniques have also been developed for measuring $\mathrm{Ca}^{2+}$ signals in specific subcellular compartments. One such technique is total internal reflection fluorescence (TIRF) microscopy, which is used to selectively visualize the area immediately beneath the plasmalemma. In TIRF microscopy, an evanescent wave is created by the reflection of a laser beam at the interface between a glass coverslip and the cytoplasm of cells attached to the coverslip (Fig. 2). Because TIRF measurements
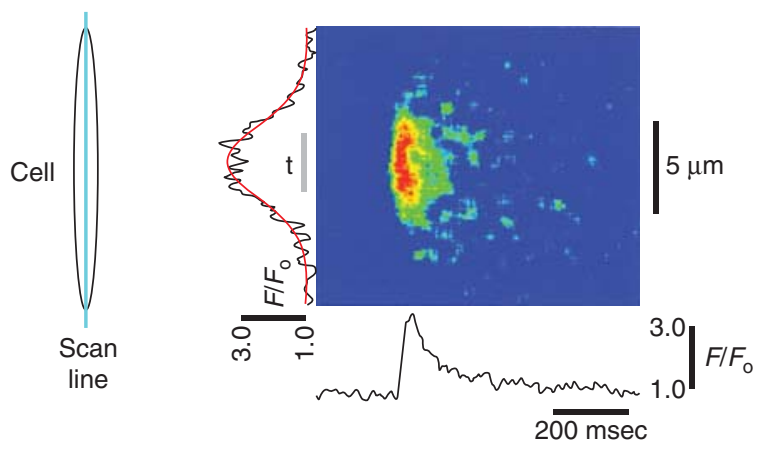

Figure 1. Line-scan imaging. The image shown demonstrates the time course of fractional fluorescence $\left(F / F_{0}\right.$; bottom) and spatial distribution of the $\mathrm{Ca}^{2+}$ spark (left) fitted to a Gaussian distribution (red line). Gray bar labeled " $\mathrm{t}$ " indicates the region over which the fluorescence time course was averaged. Scan lines are displayed vertically in a continuous manner. (Inset) Orientation of scanning line. (Adapted from Bonev et al. 1997; reprinted with permission from The American Physiological Society (C 1997.) 
D.C. Hill-Eubanks et al.

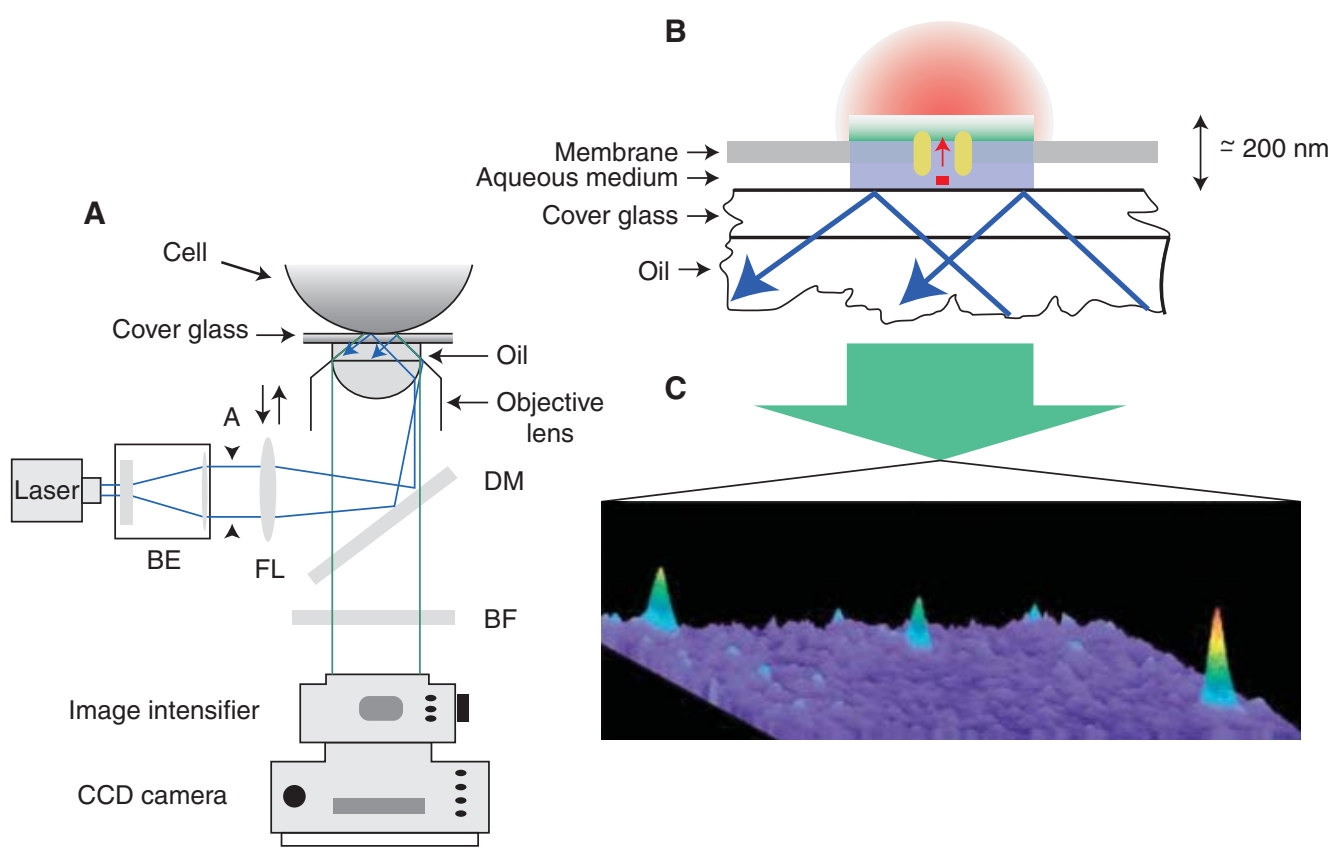

Figure 2. TIRF microscopy. (A) A schematic of the TIRF imaging system. A, adjustable rectangular knife-blade aperture; BE, beam expander; FL, focusing lens; BF, barrier filter; DM, dichroic mirror; CCD, charge-coupled device. $(B)$ Imaging membrane-proximate fluorescent $\mathrm{Ca}^{2+}$ signals near an open channel by TIRF microscopy. (C) A single frame of a TIRF microscopy video image illustrating $\mathrm{Ca}^{2+}$ signals generated by three channels within an $80 \times 80-\mu \mathrm{m}$ patch of membrane. Increasing $\mathrm{Ca}^{2+}$ concentrations are indicated by both "warmer" colors and height. (Adapted from Demuro and Parker 2004; reprinted with permission from Elsevier (C) 2004.)

usually use nonratiometric dyes, they have the same limitations noted above for these fluorophores.

\section{$\mathrm{Ca}^{2+}$ SIGNALS FROM OUTER SPACE: $\mathrm{Ca}^{2+}$ INFLUX}

\section{Signals Mediated by VDCCs}

Membrane potential depolarization activates VDCCs - the major contributors to increases in $\left[\mathrm{Ca}^{2+}\right]_{\mathrm{i}}$. VDCCs are multisubunit complexes comprising a pore-forming $\alpha 1$ subunit and regulatory $\beta, \alpha 2 \delta$, and $\gamma$ subunits (Curtis and Catterall 1984; Hosey et al. 1987; Leung et al. 1987; Vaghy et al. 1987). Most of the functional properties of the VDCC channel, including voltage sensitivity, $\mathrm{Ca}^{2+}$ permeability, $\mathrm{Ca}^{2+}$-dependent inactivation, and sensitivity to pharmacological block by organic $\mathrm{Ca}^{2+}$ channel blockers, are attributable to the $\alpha 1$ subunit. The domain organization of the $\alpha 1$ subunit creates a pseudotetrameric structure in which the four repeat domains (I, II, III, IV), each composed of six transmembrane segments (S1-6) and intracellular amino- and carboxyl-termini (Catterall 2000; Jurkat-Rott and Lehmann-Horn 2004), are analogous to the individual subunits of structurally similar, tetrameric voltage-dependent potassium $\left(\mathrm{K}^{+}\right)$channels. The $\mathrm{S} 4$ transmembrane segments of each domain serve as voltage sensors; in response to changes in membrane potential, they move outward and rotate, producing a conformational change that opens the pore (Catterall 2000).

The pore-forming $\alpha 1$ subunit is expressed as multiple splice variants with different regulatory and biophysical properties. Additional molecular diversity is provided by four different, variably spliced $\beta$ subunits (Birnbaumer et al. 1998), which further modify VDCC biophysical properties and regulate surface 
expression of the $\alpha 1$ subunit; properties of the VDCC complex may be additionally modulated by splice variants of the $\alpha 2 \delta$ regulatory subunit (Angelotti and Hofmann 1996).

VDCC-mediated currents are characterized by high voltage of activation, large single-channel conductance, and slow voltage-dependent inactivation. VDCC-mediated currents also display a characteristic sensitivity to dihydropyridines (Reuter 1983), a class of drugs used clinically in the treatment of hypertension (Nelson et al. 1990; Snutch et al. 2001). In vascular and visceral smooth muscle, these dihydropyridine-sensitive currents are attributable to the expression of the L-type VDCC pore-forming $\alpha 1 \mathrm{C}$ subunit $\left(\mathrm{Ca}_{\mathrm{V}} 1.2\right)$ (Keef et al. 2001; Moosmang et al. 2003; Wegener et al. 2004); but in some smooth muscle types, the $\alpha 1 \mathrm{D}\left(\mathrm{Ca}_{\mathrm{V}} 1.3\right)$ subunit is expressed as well (Nikitina et al. 2007). Of the four $\beta$ subunits, only two- $\beta 2$ and $\beta 3$-are clearly detected at the protein level in smooth muscle, although mRNA for all four isoforms is expressed (Hullin et al. 1992; Murakami et al. 2003).

There is also evidence for the expression of a dihydropyridine-insensitive $\mathrm{Ca}^{2+}$ current in some smooth muscle types. This T-type (transient) current is mediated by $\mathrm{Ca}_{\mathrm{V}} 3$ pore-forming $\alpha$ subunits-primarily the $\mathrm{Ca}_{\mathrm{V}} 3.1$ isoform in smooth muscle (Bielefeldt 1999; Perez-Reyes 2003). Expression of T-type channels varies between different smooth muscle types, but their presence often goes undetected because of their low levels of expression or because they are obscured by the specific recording conditions used. Moreover, the negative steadystate inactivation property of these channels results in their being half-inactivated at about $-70 \mathrm{mV}$. Therefore, over the range of smooth muscle resting membrane potential $(-50$ to $-30 \mathrm{mV}$ ), T-type channels may be completely inactivated. Because of these gating properties, the importance of T-type currents in the regulation of smooth muscle membrane potential is a matter of controversy. However, there is evidence from the rabbit urethra that, at least in this tissue, T-type channels regulate action potential frequency (Bradley et al. 2004).
It also has been suggested that voltage-dependent $\mathrm{Ca}^{2+}$ currents in smooth muscle with a T-type pharmacology may arise because of a $\mathrm{Ca}_{\mathrm{V}} 3.1$ (and/or $\mathrm{Ca}_{\mathrm{V}} 3.2$ ) splice variant with a more depolarized activation voltage (Kuo et al. 2010).

Three different $\mathrm{Ca}^{2+}$ signals mediated by VDCCs have been identified in smooth muscle: (1) global elevations in intracellular $\mathrm{Ca}^{2+}$, (2) $\mathrm{Ca}^{2+}$ "flashes," and (3) $\mathrm{Ca}^{2+}$ "sparklets."

\section{Global $\mathrm{Ca}^{2+}$ Signals}

As the name suggests, global $\mathrm{Ca}^{2+}$ signals reflect changes in $\mathrm{Ca}^{2+}$ concentration that are essentially uniform throughout the cell. In smooth muscle, depolarization of the membrane by $\sim 15 \mathrm{mV}$ from its resting potential (approximately -50 to $-40 \mathrm{mV}$ ) elevates global $\mathrm{Ca}^{2+}$ to $~ 300-400 \mathrm{nM}$, whereas hyperpolarization by $\sim 15 \mathrm{mV}$ lowers $\mathrm{Ca}^{2+}$ to $\sim 100 \mathrm{nM}$. These signals are typically monitored using ratiometric dyes (e.g., Fura-2), which are ideally suited to measuring $\mathrm{Ca}^{2+}$ concentration over this range $\left(\mathrm{K}_{\mathrm{d}} \sim 300 \mathrm{nM}\right)$. Thus, by modulating the steady-state open probability of VDCCs, slow changes in membrane potential can have profound, sustained effects on global intracellular $\mathrm{Ca}^{2+}$. This is illustrated in Figure 3, which shows that the membrane potential depolarization that accompanies elevation of intraluminal pressure from $60 \mathrm{mmHg}$ (Fig. 3A) to $100 \mathrm{mmHg}$ (Fig. 3B) increases the global intracellular $\mathrm{Ca}^{2+}$ concentration in the vascular wall. Inhibition of VDCC channels with nisoldipine decreases global $\left[\mathrm{Ca}^{2+}\right]_{\mathrm{i}}$ (Fig. 3C). Changes in global $\mathrm{Ca}^{2+}$ are accompanied by changes in vascular diameter, underscoring the importance of global $\mathrm{Ca}^{2+}$ in regulating the contractile state of smooth muscle (see below).

\section{$\mathrm{Ca}^{2+}$ Flashes}

Some types of smooth muscle (e.g., urinary bladder, gallbladder, ureter) show action potentials. These rapid, transient changes in membrane potential, which show a characteristic temporal profile, are unique to excitable cells. However, unlike other excitable cells, such as 
D.C. Hill-Eubanks et al.

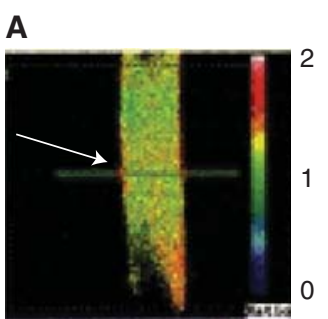

189

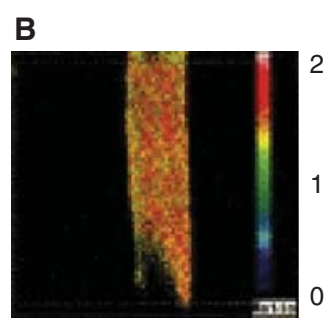

245

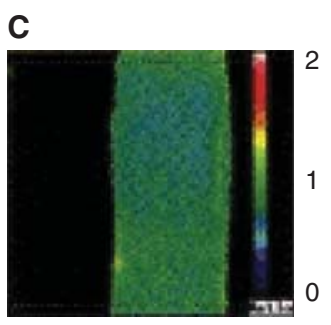

68

Figure 3. Global $\mathrm{Ca}^{2+} \cdot \mathrm{Ca}^{2+}$ images obtained from a rat basilar artery pressurized to $(A) 60 \mathrm{mmHg},(B)$ $100 \mathrm{mmHg}$, and $(C) 100 \mathrm{mmHg}$ in the presence of nisoldipine. The numbers below each panel correspond to the $\mathrm{Ca}^{2+}$ concentration in the smooth muscle of the vascular wall, calculated from the ratio of Fura-2 fluorescence at 340 and $380 \mathrm{~nm}$. Note contraction and dilation in $B$ and $C$, respectively, relative to $A$. (Adapted from Knot and Nelson 1998; reprinted with permission from The Journal of Physiology (C 1998.)

neurons and cardiac myocytes, where action potentials are initiated by activation of channels that predominantly mediate sodium $\left(\mathrm{Na}^{+}\right)$ influx, the upstroke of the action potential in smooth muscle reflects massive $\mathrm{Ca}^{2+}$ entry through VDCCs. The resulting rapid elevation of global intracellular $\mathrm{Ca}^{2+}$ can be detected optically as a $\mathrm{Ca}^{2+}$ flash that brightly and briefly lights up cells loaded with fluorescent $\mathrm{Ca}^{2+}$ indicators. A recording of a $\mathrm{Ca}^{2+}$ flash in urinary bladder smooth muscle is shown in Figure $4 . \mathrm{Ca}^{2+}$ flashes can be evoked by electrical field stimulation, but also occur spontaneously (as in the example shown), likely reflecting the spontaneous release of neurotransmitters from sympathetic (e.g., mesenteric arteries) or parasympathetic (e.g., urinary bladder) nerve terminals (Klockner and Isenberg 1985; Heppner et al. 2005). Note that in this example, $\mathrm{Ca}^{2+}$ was simultaneously elevated in two adjacent cells, indicating that these events may be coupled.

\section{$\mathrm{Ca}^{2+}$ Sparklets}

Cheng and colleagues first measured the local $\mathrm{Ca}^{2+}$ signal caused by the opening of a single L-type VDCC in cardiac muscle (Wang et al. 2001b), and referred to these events as $\mathrm{Ca}^{2+}$ sparklets. $\mathrm{Ca}^{2+}$ sparklets are also present in vascular smooth muscle (Fig. 5), where they are detected by TIRF microscopy as highly localized, dihydropyridine-sensitive, subplasmalemmal $\mathrm{Ca}^{2+}$-release events reflecting the activity of an individual channel or cluster of channels (Navedo et al. 2005). The average area of a $\mathrm{Ca}^{2+}$ sparklet is $\sim 0.8 \mu \mathrm{m}^{2}$ or $\sim 0.08 \%$ of the surface membrane of a typical arterial smooth muscle cell (Santana et al. 2008). $\mathrm{Ca}^{2+}$ influx through $\mathrm{Ca}^{2+}$ sparklet sites is quantal, and the size of a given $\mathrm{Ca}^{2+}$ sparklet depends on the number of quanta activated. One quantal unit of $\mathrm{Ca}^{2+}$ release elevates $\left[\mathrm{Ca}^{2+}\right]_{i}$ by about $35 \mathrm{~nm}$. The specific locations of $\mathrm{Ca}^{2+}$ sparklets vary between cells, but within a cell, $\mathrm{Ca}^{2+}$ sparklets are predominantly stationary events that occur in specific regions of the sarcolemmal membrane (Fig. 5A-C). Both low- and high-activity $\mathrm{Ca}^{2+}$ sparklet sites have been described. The frequency of the latter type of event, termed a persistent sparklet, is increased by activation of protein kinase $\mathrm{C}(\mathrm{PKC})$, which recruits previously silent sites and increases the frequency of low-activity sites (Fig. 5D).

In heart muscle, where local coupling of $\mathrm{Ca}^{2+}$ influx through single VDCCs to RyRs is central to excitation-contraction coupling (Cannell et al. 1995; Lopez-Lopez et al. 1995), $\mathrm{a} \mathrm{Ca}^{2+}$ sparklet can activate four to six nearby RyRs to cause a $\mathrm{Ca}^{2+}$ spark (see below). However, there is no evidence for this direct VDCC-to-RyR communication in smooth muscle. Instead, $\mathrm{Ca}^{2+}$ currents through VDCCs appear to activate RyRs indirectly through elevations in global $\mathrm{Ca}^{2+}$ and $\mathrm{SR} \mathrm{Ca}^{2+}$ load (Collier et al. 2000; Herrera and Nelson 2002; Wellman and Nelson 2003; Essin and Gollasch 2009). 
A (a)

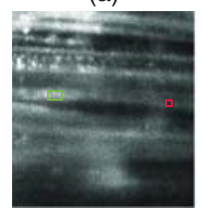

B

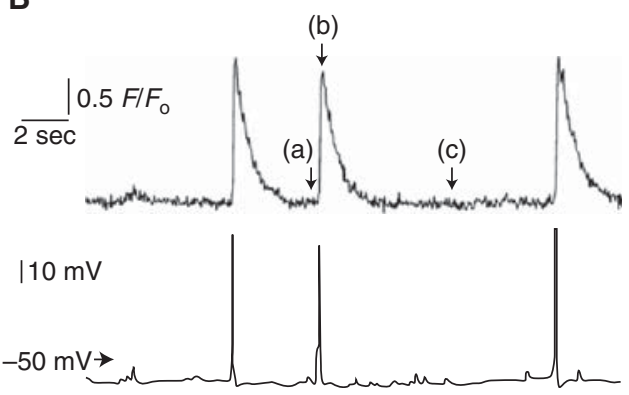

(b)
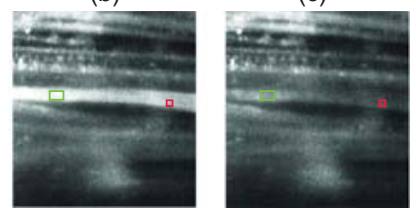

$\overline{25 \mu \mathrm{m}}$

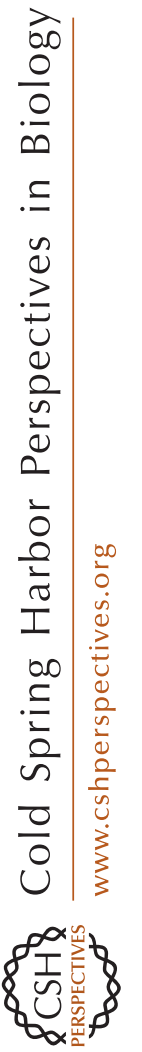

Figure 4. $\mathrm{Ca}^{2+}$ flashes. (A) Selected images recorded before (a), during (b), and after (c) a spontaneous action potential in a smooth muscle bundle loaded with Fluo-4 and impaled with a microelectrode (green rectangle). (B) Simultaneous recordings of changes in $\mathrm{Ca}^{2+}$-activated fluorescence (upper trace) and voltage (lower trace) from a single bundle of urinary bladder smooth muscle. Changes in $\mathrm{Ca}^{2+}$ activated fluorescence were measured from the red box in $A$; the letters $\mathrm{a}, \mathrm{b}$, and $\mathrm{c}$ denote the times at which the correspondingly labeled images in $A$ were acquired. Note that each of the three action potentials induced a simultaneous increase in $\mathrm{Ca}^{2+}$-activated fluorescence. (Adapted from Heppner et al. 2005; reprinted with permission from The Journal of Physiology (C) 2005.)

\section{Signals Mediated by Store-Operated} $\mathrm{Ca}^{2+}$ Channels

Extracellular $\mathrm{Ca}^{2+}$ influx in response to depletion of intracellular $\mathrm{Ca}^{2+}$ stores, a process termed store-operated $\mathrm{Ca}^{2+}$ entry (SOCE), is known to play an important role in a number of cell types, notably nonexcitable cells. However, the molecular mechanism underlying this coupling long remained elusive. Recent seminal work by a number of independent groups effectively resolved this question, clearly identifying ubiquitously expressed STIM proteins (Liou et al. 2005; Roos et al. 2005) as endoplasmic reticulum (ER) $\mathrm{Ca}^{2+}$ sensors, and members of the Orai family (Feske et al. 2006; Vig et al. 2006; Zhang et al. 2006) of transmembrane proteins as the entities responsible for mediating $\mathrm{Ca}^{2+}$ entry (reviewed in Varnai et al. 2009). These researchers showed that, in response to a decrease in $\mathrm{ER} \mathrm{Ca}^{2+}$ concentrations, the low-affinity $\mathrm{Ca}^{2+}$-binding STIM proteins aggregate to form discrete plasmalemmal-proximate clusters that tether Orai proteins. This physical coupling activates Orai, which is a highly selective $\mathrm{Ca}^{2+}$ channel, thereby promoting extracellular $\mathrm{Ca}^{2+}$ entry. The identification of the STIM-Orai mechanism has sparked renewed interest in investigating SOCE in smooth muscle (reviewed in Wang et al. 2008). These studies, most of which have been performed using cultured smooth muscle cells, have consistently shown that STIM and Orai family members are expressed in smooth muscle, and, under the conditions tested, are capable of functionally coupling store depletion to extracellular $\mathrm{Ca}^{2+}$ entry (Peel et al. 2006, 2008; Takahashi et al. 2007; $\mathrm{Ng}$ et al. 2010; Park Hopson et al. 2011). It has also been suggested that, in addition to promoting Orai activity, STIM1 negatively regulates VDCCs (Wang et al. 2010). Some recent studies have provided evidence for STIM-Orai coupling in native smooth muscle preparations, and have suggested a role for this mechanism in hypertension (Giachini et al. 2009, 2010). An optical signature of Orai-mediated $\mathrm{Ca}^{2+}$ influx has not been defined and additional research will be required to definitively establish the physiological relevance of this pathway in native smooth muscle tissues.

\section{Signals Mediated by Nonselective Cation Channels}

In contrast to VDCCs, which show a high selectivity for $\mathrm{Ca}^{2+}$ ions over monovalent cations, nonselective cation channels typically also allow influx of extracellular $\mathrm{Na}^{+}$. Although channels of this type are permeable to $\mathrm{Ca}^{2+}$ and thus directly increase $\left[\mathrm{Ca}^{2+}\right]_{\mathrm{i}}$ to some degree, in many if not most cases, their major impact on $\left[\mathrm{Ca}^{2+}\right]_{\mathrm{i}}$ is indirect through $\mathrm{Na}^{+}$-dependent membrane potential depolarization and activation of 
D.C. Hill-Eubanks et al.
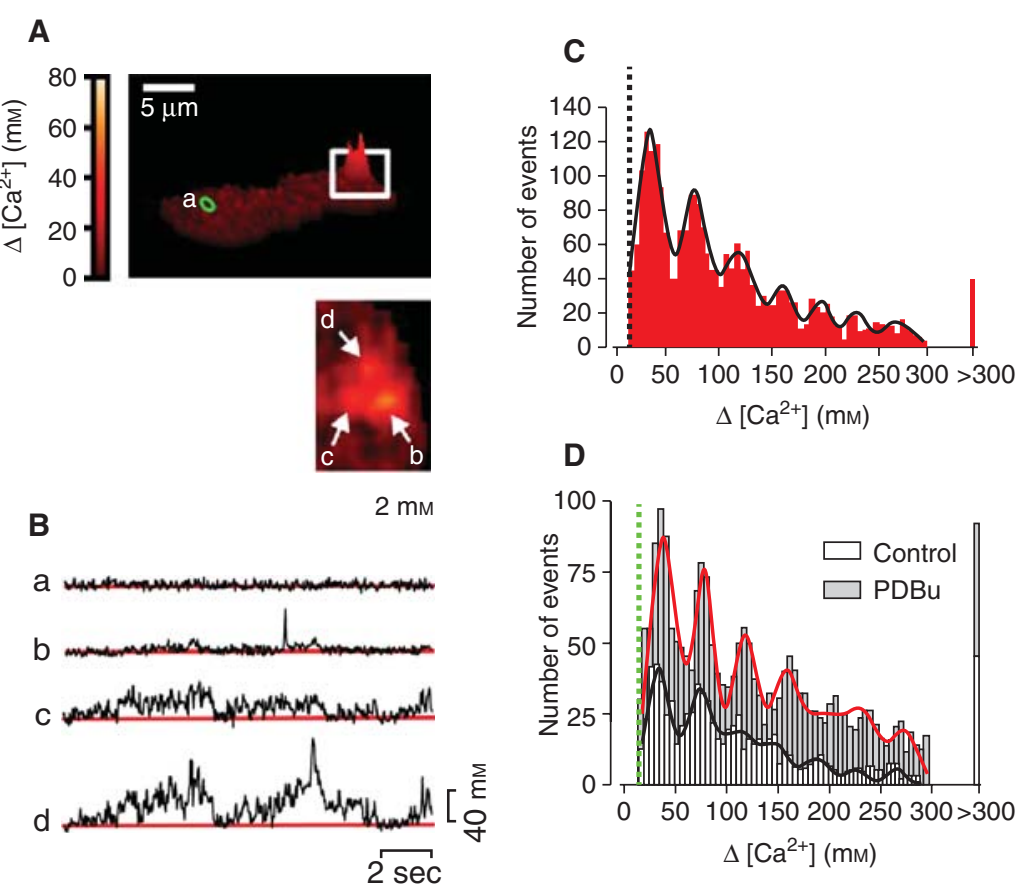

Figure 5. $\mathrm{Ca}^{2+}$ sparklets. (A) Surface plot of $\mathrm{Ca}^{2+}$ imaged in a freshly isolated arterial myocyte. (Inset) Higher magnification view of boxed area showing three active $\mathrm{Ca}^{2+}$ sparklet sites $\left(2 \mathrm{~mm}\right.$ extracellular $\left.\mathrm{Ca}^{2+}\right)$. (B) Traces showing time course of changes in $\mathrm{Ca}^{2+}$ at sites a-d. (C) Amplitude histogram of $\mathrm{Ca}^{2+}$ sparklets (20 mu extracellular $\left.\mathrm{Ca}^{2+}\right)$. (D) Amplitude histogram of $\mathrm{Ca}^{2+}$ sparklets $\left(2 \mathrm{~mm}\right.$ extracellular $\left.\mathrm{Ca}^{2+}\right)$ in the absence and presence of the PKC activator phorbol 12,13-dibutyrate (PDBu). Solid lines in $C$ and $D$ are best fits to a Gaussian function. (Adapted from Navedo et al. 2005; reprinted with permission from The National Academy of Sciences (C) 2005.)

VDCCs. Several types of $\mathrm{Ca}^{2+}$-permeable, nonselective cation channels are present in smooth muscle, including receptor-activated channels, mechanosensitive channels, tonically active channels, and channels activated by SR $\mathrm{Ca}^{2+}$ store depletion.

\section{Receptor-Activated Cation Channels}

Of the various nonselective cation channels expressed in smooth muscle, only the ATPgated $\mathrm{P} 2 \mathrm{X}$ receptor (P2XR) is clearly associated with an optically identifiable $\mathrm{Ca}^{2+}$ signal. The functional P2XR complex is thought to be a trimer (Aschrafi et al. 2004) —an unusual structural arrangement in ion-channel space where tetramers dominate. Each subunit contains intracellular amino- and carboxyl-termini and two membrane-spanning domains that are connected by a large extracellular domain (Khakh 2001; North 2002). Binding of ATP (three molecules per complex) to a site in the large extracellular domain induces a conformational change that results in rapid (milliseconds) opening of the pore.

These $\mathrm{Ca}^{2+}$ - and $\mathrm{Na}^{+}$-permeable channels (Benham and Tsien 1987; Schneider et al. 1991) mediate a rapid local influx of $\mathrm{Na}^{+}$and $\mathrm{Ca}^{2+}$ at nerve-muscle junctions following activation by neurally released ATP (Lamont and Wier 2002; Lamont et al. 2006). The influx of $\mathrm{Na}^{+}$and $\mathrm{Ca}^{2+}$ creates an excitatory junction potential (EJP) that contributes directly to the increase in postjunctional excitability. Multiple lines of evidence, including studies using knockout mice, indicate that the $\mathrm{P}_{2} \mathrm{X}_{1}$ receptor is the predominant $\mathrm{P} 2 \mathrm{X}$ receptor isoform expressed in smooth muscle (Mulryan et al. 
2000; Vial and Evans 2002; Lamont et al. 2006; Heppner et al. 2009).

Although most of the excitatory junction current (EJC) associated with $\mathrm{P}_{2} \mathrm{X}_{1}$ receptor activation is carried by the more abundant $\mathrm{Na}^{+}$ ions, $\mathrm{Ca}^{2+}$ influx is substantial. This influx can be detected optically in the form of local elementary purinergic-induced $\mathrm{Ca}^{2+}$ transients (Fig. 6). These events have been described in vas deferens (Brain et al. 2002), mesenteric arteries (Lamont and Wier 2002), and urinary bladder (Heppner et al. 2005), where they have been termed neuroeffector $\mathrm{Ca}^{2+}$ transients (NCTs), junctional $\mathrm{Ca}^{2+}$ transients ( jCaTs), and nerve-evoked elementary purinergic $\mathrm{Ca}^{2+}$ transients, respectively. The kinetic properties of these purinergic $\mathrm{Ca}^{2+}$ signals are similar to one another and are clearly distinct from those of other local $\mathrm{Ca}^{2+}$ transients (HillEubanks et al. 2010).

\section{Other Nonselective Cation Channels}

Smooth muscle cells express a number of nonselective cation channels of the TRP family. Although no signature signaling event associated with $\mathrm{Ca}^{2+}$ influx through TRP channels has been reported in the literature, given the relative selectivity of these channels for $\mathrm{Ca}^{2+}$ (and the high $\mathrm{Ca}^{2+}$ permeability and single-channel conductance of some TRP family members, notably TRPV), imaging methods that have been used to examine jCaT-like events (confocal microscopy) and/or VDCC-mediated sparklets (TIRF) may ultimately provide a means to optically detect $\mathrm{Ca}^{2+}$ influx through these channels.

\section{$\mathrm{Ca}^{2+}$ SIGNALS FROM INNER SPACE: RELEASE OF $\mathrm{Ca}^{2+}$ FROM INTRACELLULAR STORES}

The most important intracellular $\mathrm{Ca}^{2+}$ store in smooth muscle is the SR. Cytosolic $\mathrm{Ca}^{2+}$ is transported into the SR by the action of the SR/ER Ca ${ }^{2+}$ ATPase (SERCA). SERCA activity is negatively regulated by the protein phospholamban, a target of protein kinase A (PKA) and protein kinase $\mathrm{G}$ (PKG). On phosphorylation, the SERCA inhibitory activity of phospholamban is lost, increasing $\mathrm{Ca}^{2+}$ uptake and SR $\mathrm{Ca}^{2+}$ load. Free $\mathrm{Ca}^{2+}$ taken up by the SR is buffered by $\mathrm{Ca}^{2+}$-binding proteins, which retain transported $\mathrm{Ca}^{2+}$ and reduce the free $\mathrm{Ca}^{2+}$
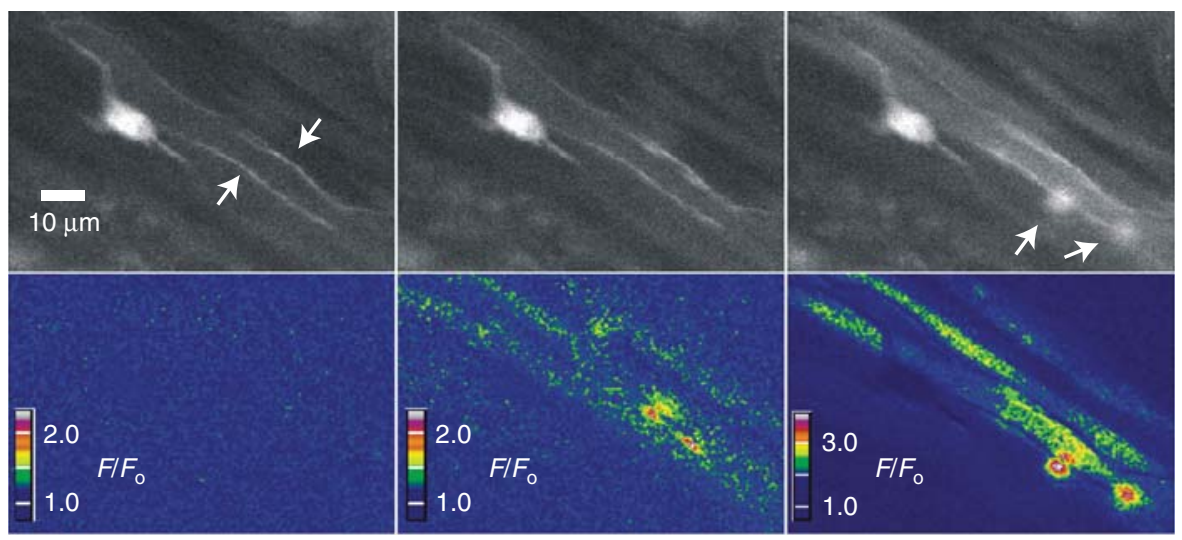

Figure 6. Elementary purinergic $\mathrm{Ca}^{2+}$ transients recorded from urinary bladder smooth muscle. Transient events were evoked by electrical field stimulation $\left(2-\mathrm{sec}\right.$ train, $\left.5 \mathrm{~Hz} ; 37^{\circ} \mathrm{C}\right)$ in bladder strips loaded with Fluo- 4 and scanned at a rate of 30 images/sec. The top three images illustrate nerve processes before (top panel, left, indicated by arrows) and after stimulation (middle and right panels). The three bottom panels illustrate color-coded ratios $\left(F / F_{0}\right)$ of the images above. Intracellular $\mathrm{Ca}^{2+}$ increases first in the nerve fibers, and then two local $\mathrm{Ca}^{2+}$ transients are detected (right panel, bottom right quadrant, indicated by arrows). The activity of $\mathrm{Ca}^{2+}$ transients continued throughout the duration of field stimulation. (Unpublished data from Mark Nelson.) 
D.C. Hill-Eubanks et al.

concentration gradient, facilitating continued $\mathrm{Ca}^{2+}$ uptake from the cytoplasm (Pozzan et al. 1994).

$\mathrm{Ca}^{2+}$ sequestered in the SR may be delivered to the cytosol through RyRs and $\mathrm{IP}_{3}$ receptors in the SR membrane. Although these two channel types are phenotypically similar on a superficial level (both function to release $\mathrm{Ca}^{2+}$ from SR stores) they are very different molecular entities with distinctive regulatory features and characteristic $\mathrm{Ca}^{2+}$-release signatures.

\section{Signals Mediated by RyRs: $\mathrm{Ca}^{2+}$ Sparks}

There are three RyR subtypes (RyR1-3), each of which is expressed at varying levels in different smooth muscle tissues (Neylon et al. 1995; Yang et al. 2005; Prinz and Diener 2008). RyRs are large tetrameric complexes formed from $\sim 560-\mathrm{kDa}$ subunits. Each subunit contains four membrane-spanning domains, a large cytosol-facing amino-terminal region containing the $\mathrm{Ca}^{2+}$-binding site as well as binding sites for numerous accessory proteins, and a short SR-luminal carboxy-terminal domain (reviewed in Zalk et al. 2007; Lanner et al. 2010).

$\mathrm{Ca}^{2+}$ flux through ryanodine receptors is detectable in the form of elementary release events termed $\mathrm{Ca}^{2+}$ sparks. First discovered in cardiac muscle (Cheng et al. 1993) and subsequently identified in skeletal (Klein et al. 1996) and smooth (Nelson et al. 1995) muscle, a $\mathrm{Ca}^{2+}$ spark represents the opening of a few (likely four to six) RyR channels in the SR membrane (Cheng and Lederer 2008). $\mathrm{Ca}^{2+}$ sparks have been detected in a wide variety of smooth muscle types, including those from arteries (Nelson et al. 1995), portal vein (Mironneau et al. 1996; Gordienko and Bolton 2002), urinary bladder (Herrera et al. 2001), ureter (Burdyga and Wray 2005), airway (Sieck et al. 1997), and the gastrointestinal tract (Gordienko et al. 1998). $\mathrm{Ca}^{2+}$ sparks in arterial smooth muscle can be detected in isolated myocytes as well as in intact pressurized arteries. $\mathrm{Ca}^{2+}$ sparks are rapid, transient, stationary events. The rise time of sparks in vascular smooth muscle and urinary bladder smooth muscle is $\sim 20-40 \mathrm{msec}$ (Nelson et al. 1995; Herrera et al. 2001); their spatial spread is $\sim 12.6 \mu \mathrm{m}$, and this spread corresponds to $\sim 1 \%$ of the surface membrane. The duration (half-time) of these events is $\sim 50$ $60 \mathrm{msec}$; this contrasts with nerve-evoked purinergic $\mathrm{Ca}^{2+}$ transients, which have half-times of $\sim 110-145$ msec (Brain et al. 2002; Lamont and Wier 2002; Heppner et al. 2005). Current evidence indicates that smooth muscle $\mathrm{Ca}^{2+}$ sparks are attributable to activation of RyR2, although both RyR1 and RyR3 may influence spark activity (Vaithianathan et al. 2010).

In smooth muscle, localized increases in $\mathrm{Ca}^{2+}$ associated with $\mathrm{Ca}^{2+}$ sparks activate closely juxtaposed large-conductance, $\mathrm{Ca}^{2+}$ activated $\mathrm{K}^{+}\left(\mathrm{BK}_{\mathrm{Ca}}\right)$ channels in the plasma membrane. The $\mathrm{K}_{\mathrm{d}}$ of $\mathrm{BK}_{\mathrm{Ca}}$ channels for $\mathrm{Ca}^{2+}$ is $\sim 20 \mu \mathrm{M}$ at the physiological membrane potential of $-40 \mathrm{mV}$. A single spark causes a local increase of $\left[\mathrm{Ca}^{2+}\right]_{\mathrm{i}}$ of $10-30 \mu \mathrm{M}$ and activates about 30 nearby $\mathrm{BK}_{\mathrm{Ca}}$ channels, increasing their open probability by approximately 100-fold (Jaggar et al. 2000; Perez et al. 2001). In smooth muscle from adult animals, there is a one-to-one relationship between sparks and $\mathrm{BK}_{\mathrm{Ca}}$ channel-mediated transient outward currents, indicating that all spark sites are functionally coupled to $\mathrm{BK}_{\mathrm{Ca}}$ channel clusters. In current-clamp mode, activation of $\mathrm{BK}_{\mathrm{Ca}}$ channels by a single spark causes about a $20-\mathrm{mV}$ hyperpolarization (Jaggar et al. 1998b).

Stimuli that increase SR $\mathrm{Ca}^{2+}$ load increase the frequency of $\mathrm{Ca}^{2+}$ sparks, but sparks also occur spontaneously. The outward currents associated with this latter activity are termed "spontaneous transient outward currents" or "STOCs" (Benham and Bolton 1986). An example depicting the time course and decay kinetics of a single $\mathrm{Ca}^{2+}$ spark event is presented in Figure 7A. Simultaneous electrophysiological recordings and traces showing analyzed $\mathrm{Ca}^{2+}$ signals (Fig. 7B) highlight the one-to-one relationship between sparks and STOCs.

In addition to activating $\mathrm{BK}_{\mathrm{Ca}}$ channels to produce STOCs, $\mathrm{Ca}^{2+}$ sparks can also activate $\mathrm{Ca}^{2+}$-sensitive chloride $\left(\mathrm{Cl}_{\mathrm{Ca}}\right)$ channels to produce spontaneous transient inward currents (STICs) (Hogg et al. 1993). Where $\mathrm{BK}_{\mathrm{Ca}}$ and $\mathrm{Cl}_{\mathrm{Ca}}$ channels coexist, spontaneous transient outward/inward currents (STOICs) are 
A

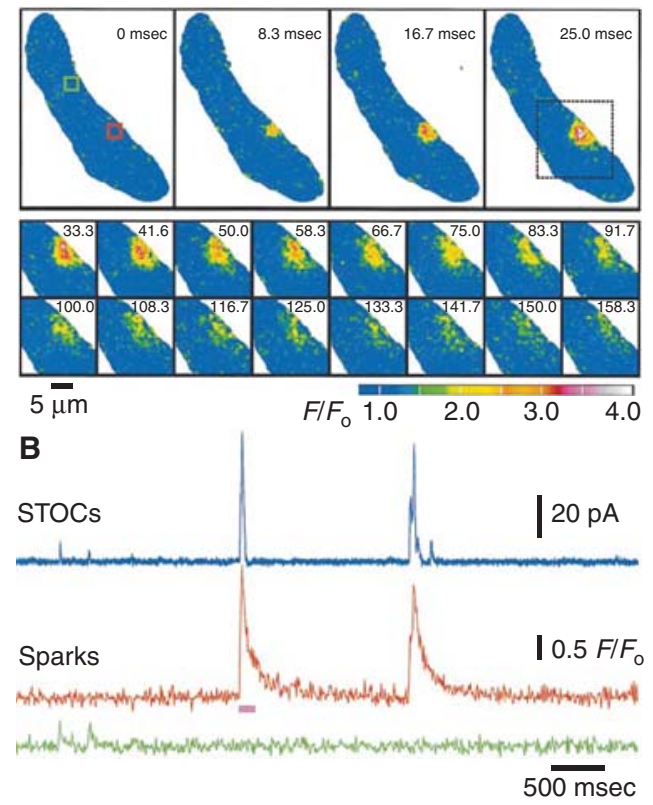

Figure 7. $\mathrm{Ca}^{2+}$ sparks in an isolated rat basilar artery myocyte. (A) (Top) Two-dimensional confocal images of an entire smooth muscle cell showing the time course of the fractional increase in Fluo-3 fluorescence $\left(F / F_{0}\right)$ of a typical $\mathrm{Ca}^{2+}$ spark. (Bottom) Images obtained from the region of interest in the top-right panel (dotted box) depicting spark decay. Pseudocolor denotes relative $\mathrm{Ca}^{2+}$ levels as indicated by the bar. (B) Simultaneous measurements of STOCs and sparks at $-40 \mathrm{mV}$ highlighting the temporal association between the events. The pink bar below the sparks trace corresponds to the time period imaged in A. (Adapted from Perez et al. 1999; reprinted with permission from The Rockefeller University Press (C) 1999.)

produced (ZhuGe et al. 1998; Jaggar et al. 2000; Wellman and Nelson 2003). Both hyperpolarizing (STOCs) and depolarizing currents (STICs) modulate membrane potential and excitability, with STOCs being inhibitory and STICs being excitatory.

\section{Signals Mediated by IP ${ }_{3} \mathrm{Rs}: \mathrm{Ca}^{2+}$ Waves}

There are three $\mathrm{IP}_{3}$ receptor subtypes $\left(\mathrm{IP}_{3} \mathrm{R} 1-3\right)$, each of which is expressed at varying levels in different smooth muscle tissues (Newton et al. 1994; Tasker et al. 1999; Boittin et al. 2000;
Grayson et al. 2004). IP ${ }_{3}$ Rs are large homo- or heterotetrameric complexes formed from approximately 2700 to 2800 amino acid subunits. Each subunit contains six membrane-spanning domains, a large cytosol-facing amino-terminal region containing the $\mathrm{IP}_{3}$ binding site, and a short cytosolic carboxy-terminal domain. The pore of the channel is formed by the coassociation of transmembrane domains 5 and 6 from each of the four subunits (Foskett et al. 2007).

$\mathrm{Ca}^{2+}$ release by $\mathrm{IP}_{3} \mathrm{Rs}$ is regulated by two second messengers: $\mathrm{IP}_{3}$ and $\mathrm{Ca}^{2+}$. The prototypical signaling pathway that leads to elevation of $\mathrm{IP}_{3}$ is activation of $\mathrm{G} \alpha_{\mathrm{q} / 11}$-type $\mathrm{G}$ proteincoupled receptors. Among the most prominent agonists of this pathway in smooth muscle are neurohumoral vasoconstrictors. Activation of this pathway stimulates phospholipase C, resulting in hydrolysis of membrane-associated phosphoinositide 4,5-bisphosphate $\left(\mathrm{PIP}_{2}\right)$ into $\mathrm{IP}_{3}$ and diacyclglycerol. The $\mathrm{IP}_{3}$ generated by this pathway binds $\mathrm{IP}_{3} \mathrm{Rs}$ and promotes channel gating, releasing $\mathrm{Ca}^{2+}$ into the cytosol. The $\mathrm{Ca}^{2+}$ released by $\mathrm{IP}_{3} \mathrm{Rs}$ can reciprocally modulate $\mathrm{IP}_{3} \mathrm{R}$ activity in two ways: as $\mathrm{Ca}^{2+}$ rises from low nanomolar basal levels to low micromolar levels in the vicinity of the channel, it activates $\mathrm{IP}_{3} \mathrm{Rs}$; at higher local levels, the channel becomes inactivated. These activation/inactivation properties together with regulation of channel function by multiple interacting factors, allow $\mathrm{IP}_{3} \mathrm{Rs}$ to generate a large variety of temporally and spatially modulated $\mathrm{Ca}^{2+}$ signaling patterns within the cell (Foskett et al. 2007).

In some smooth muscle types, $\mathrm{IP}_{3} \mathrm{R}-$ mediated $\mathrm{Ca}^{2+}$ release is transient and localized. For example, smooth muscle cells from colon and portal vein show spontaneous $\mathrm{Ca}^{2+}$ spark-like events that are enhanced by $\mathrm{IP}_{3}$ production and eliminated by $\mathrm{IP}_{3} \mathrm{R}$ blockade (Bayguinov et al. 2000; Gordienko and Bolton 2002). These $\mathrm{Ca}^{2+}$ release events, termed $\mathrm{Ca}^{2+}$ "puffs," have a biophysical signature (e.g., kinetics, magnitude, spatial spread) that distinguishes them from the RyR-mediated $\mathrm{Ca}^{2+}$ sparks that are prominent in most other smooth muscle types (e.g., vascular smooth muscle, gallbladder, and urinary bladder) (Nelson et al. 1995; 
D.C. Hill-Eubanks et al.

Herrera et al. 2001; Pozo et al. 2002). Although $\mathrm{Ca}^{2+}$ puffs are unitary events, they can act as initiation sites for intracellular $\mathrm{Ca}^{2+}$ waves and thereby contribute to global $\mathrm{Ca}^{2+}$ signals (Bootman and Berridge 1996; Thomas et al. 1998).

$\mathrm{A} \mathrm{Ca}^{2+}$ wave, defined as an increase in $\left[\mathrm{Ca}^{2+}\right]_{\mathrm{i}}$ that propagates across the entire smooth muscle cell from an initial site of release, is perhaps the most studied $\mathrm{IP}_{3} \mathrm{R}$-mediated $\mathrm{Ca}^{2+}{ }_{-}$ signaling event. First described by lino in rat tail arteries (Fig. 8), $\mathrm{Ca}^{2+}$ waves are a common feature of vascular smooth muscle cells exposed

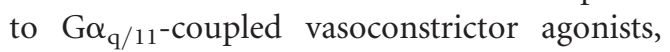
such as UTP (Jaggar and Nelson 2000) and norepinephrine (Iino et al. 1994; Boittin et al. 1999; Miriel et al. 1999; Ruehlmann et al. 2000), or electrical field stimulation of perivascular nerves.

In the current view, $\mathrm{Ca}^{2+}$ waves reflect the activation/inactivation properties of $\mathrm{IP}_{3} \mathrm{Rs}$, and arise through a regenerative $\mathrm{Ca}^{2+}$-induced $\mathrm{Ca}^{2+}$ release (CICR) mechanism. $\mathrm{Ca}^{2+}$ released from the $\mathrm{SR}$ acts on successive adjacent $\mathrm{IP}_{3} \mathrm{Rs}$ or $\mathrm{IP}_{3} \mathrm{R}$ clusters in a cascading fashion, creating a leading edge of $\mathrm{Ca}^{2+}$ elevation that traverses the length of the cell. When $\mathrm{Ca}^{2+}$ waves propagate toward each other and collide, they cancel each other out because of depletion of SR $\mathrm{Ca}^{2+}$ stores on either side of the collision site (Stevens et al. 1999). Therefore, a continuous cycling of $\mathrm{SR} \mathrm{Ca}^{2+}$ release and reuptake maintains the $\mathrm{Ca}^{2+}$ waveform. $\mathrm{Ca}^{2+}$ released from SR stores is sufficient for further release and maintenance of $\mathrm{Ca}^{2+}$ waves, indicating that the mechanism of smooth muscle $\mathrm{Ca}^{2+}$ wave propagation is independent of extracellular $\mathrm{Ca}^{2+}$ entry (Boittin et al. 1999; Jaggar and Nelson 2000; Peng et al. 2001; Heppner et al. 2002). Repeating $\mathrm{IP}_{3} \mathrm{R}$-dependent $\mathrm{Ca}^{2+}$ signals may also take the form of whole-cell oscillations in $\left[\mathrm{Ca}^{2+}\right]_{\mathrm{i}}$.

The view of $\mathrm{Ca}^{2+}$ waves as strictly $\mathrm{IP}_{3} \mathrm{R}$ mediated events oversimplifies the true situation. In actuality, $\mathrm{Ca}^{2+}$ waves arise in response to activation of $\mathrm{IP}_{3} \mathrm{Rs}$ and/or RyRs (Iino et al. 1994; Boittin et al. 1999; Hirose et al. 1999; Jaggar and Nelson 2000; Lee et al. 2002), and their properties as well as the relative contributions of $\mathrm{IP}_{3} \mathrm{Rs}$ and RyRs may differ depending on the nature of the stimulus or tissue context. In some cases, these events appear to exclusively reflect the activity of RyRs. One such example is provided by rat cerebral arteries, where Nelson and colleagues (Heppner et al. 2002)

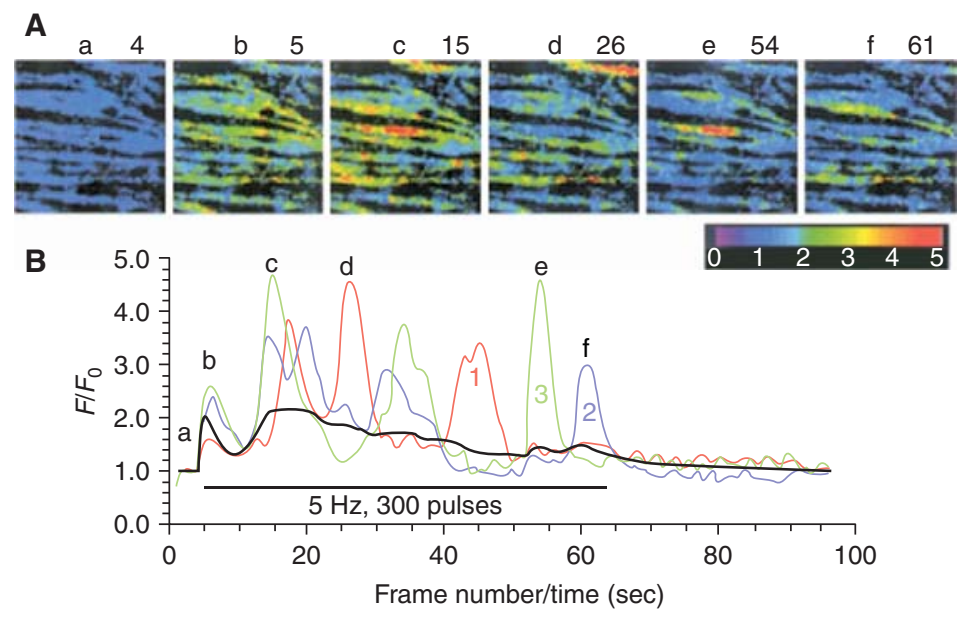

Figure 8. $\mathrm{Ca}^{2+}$ waves. (A) Two-dimensional pseudocolor confocal microscopic images of rat tail artery smooth muscle showing dynamic, recurrent changes in intracellular $\mathrm{Ca}^{2+}$ (measured by changes in the intensity of Fluo-3 fluorescence) following electrical stimulation of perivascular sympathetic nerves. Six of 96 consecutive frames collected at a rate of one frame per second are shown. $(B)$ Red, blue, and green lines depict changes in fluorescence intensity as a function of time $(a-f$ in $A)$ in three selected regions of interest (white boxes in $a$ ). (Adapted from Iino et al. 1994; reprinted with permission from The EMBO Journal (C) 1994.) 
have found that $\mathrm{Ca}^{2+}$ waves are induced by caffeine, which acts on RyRs but not $\mathrm{IP}_{3}$ Rs. Moreover, these events are insensitive to the nominally selective $\mathrm{IP}_{3} \mathrm{R}$ blockers, xestospongin $\mathrm{C}$ and 2-aminoethoxydiphenyl borate (2-APB), but are completely eliminated by ryanodine. Interestingly, RyR-mediated $\mathrm{Ca}^{2+}$ signaling in this preparation is sharply dependent on $\mathrm{pH}$. Increasing the $\mathrm{pH}$ of the bathing solution from 7.4 to 7.5 increased $\mathrm{Ca}^{2+}$ spark frequency by $\sim 50 \%$; above this $\mathrm{pH}, \mathrm{Ca}^{2+}$ waves came to predominate, increasing approximately threefold between $\mathrm{pH} 7.5$ and $\mathrm{pH} 7.6$ and doubling again at $\mathrm{pH} 7.7-7.8$.

\section{FUNCTIONAL CORRELATES OF $\mathrm{Ca}^{2+}$ SIGNALS}

\section{Contractility}

Smooth muscle contraction is driven by $\mathrm{Ca}^{2+}$ calmodulin activation of myosin light chain kinase, which has a $\mathrm{Ca}^{2+}$ half-activation of $\sim 400 \mathrm{~nm}$ (Stull et al. 1998). The gain of smooth muscle contraction to $\mathrm{Ca}^{2+}$ can be adjusted through regulation of myosin light chain phosphatase (Somlyo and Somlyo 2003; Mizuno et al. 2008).

\section{Global $\mathrm{Ca}^{2+}$}

Membrane potential plays an important role in all excitable cells, including smooth muscle, where it regulates $\left[\mathrm{Ca}^{2+}\right]_{\mathrm{i}}$ and thereby smooth muscle contraction. The resting membrane potential of smooth muscle is approximately -50 to $-40 \mathrm{mV}$, which is positive to the equilibrium potential for $\mathrm{K}^{+}\left(\mathrm{E}_{\mathrm{K}}\right)$. In arterial smooth muscle, this membrane potential is sufficient to increase the steady-state open probability of VDCCs, elevate global intracellular $\mathrm{Ca}^{2+}$ from $\sim 100 \mathrm{~nm}$ to $\sim 200 \mathrm{~nm}$, and cause a tonic constriction (Knot and Nelson 1998). As noted above, membrane potential hyperpolarization to $-60 \mathrm{mV}$ lowers $\mathrm{Ca}^{2+}$ to about $100 \mathrm{~nm}$, and depolarization to about $-30 \mathrm{mV}$ elevates global $\mathrm{Ca}^{2+}$ to $\sim 300-400 \mathrm{~nm}$; these changes in global intracellular $\mathrm{Ca}^{2+}$ are sufficient to cause maximal dilation and constriction, respectively. The fundamental relationship between global $\mathrm{Ca}^{2+}$ and smooth muscle membrane potential is depicted in Figure 9, which

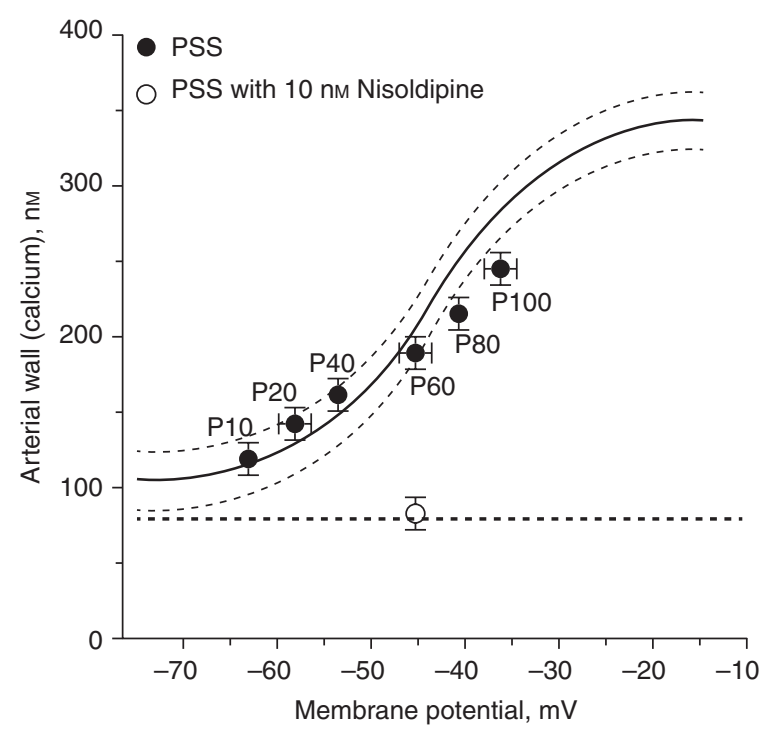

Figure 9. Intravascular pressure-membrane potential- $\left[\mathrm{Ca}^{2+}\right]_{\mathrm{i}}$ relationships. Fundamental relationships among intravascular pressure $\left(\mathrm{P} 10-\mathrm{P} 100\right.$, in $\mathrm{mm} \mathrm{Hg}$ ), membrane potential, and arterial wall $\mathrm{Ca}^{2+}$. (Adapted from Knot and Nelson 1998; reprinted with permission from The Journal of Physiology (C) 1998.) 
D.C. Hill-Eubanks et al.

also highlights the role of intravascular pressure as a physiological driver of changes in membrane potential. Oscillations in membrane potential caused by fluctuations in $\mathrm{Ca}^{2+}$ entry through VDCCs lead to vasomotion of the arterial wall.

\section{Junctional $\mathrm{Ca}^{2+}$ Transients and $\mathrm{Ca}^{2+}$ Flashes}

Nerve stimulation-evoked localized $\mathrm{Ca}^{2+}$ influx through $\mathrm{P}_{2} \mathrm{X}_{1} \mathrm{R}$ channels causes a depolarizing current carried by $\mathrm{Na}^{+}$and $\mathrm{Ca}^{2+}$ ions that activates VDCCs; in urinary bladder smooth muscle, this manifests as a $\mathrm{Ca}^{2+}$ flash. Coordinated flash activity among smooth muscle cells in a bundle leads to a transient contraction. Thus, junctional $\mathrm{Ca}^{2+}$ transients mediated by $\mathrm{P}_{2} \mathrm{X}_{1}$ Rs may indirectly modulate contraction by triggering VDCC activity.

The bursts of local elevations in intracellular $\mathrm{Ca}^{2+}$ provided by junctional $\mathrm{Ca}^{2+}$ transients also have the potential to trigger activation of proximate RyRs in the SR through a CICR mechanism. The best evidence for the existence of such a mechanism comes from studies of the vas deferens by Cunnane and coworkers (Brain et al. 2003). In this preparation, the magnitude of neurally evoked, ATP-induced $\mathrm{Ca}^{2+}$ transients was reduced by $\sim 45 \%$ by inhibition of RyRs with ryanodine. Moreover, treatment with caffeine to increase RyR activity produced a 16-fold increase in the frequency of neurally evoked junctional $\mathrm{Ca}^{2+}$ transients. Collectively, these results argue that the neurally evoked $\mathrm{Ca}^{2+}$ signal associated with extracellular $\mathrm{Ca}^{2+}$ influx triggers - and merges with-a RyR-mediated $\mathrm{Ca}^{2+}$ signal, creating an optically detectable signal that reflects a summation of the two separate transient release events. The more modest inhibitory effect of ryanodine on jCaTs in mesenteric arteries $(\sim 13 \%)$ (Lamont and Wier 2002) and the apparent absence of an effect of ryanodine on purinergic $\mathrm{Ca}^{2+}$ transients in rat urinary bladder (Heppner et al. 2005) suggest a degree of variability among tissues and species. How (or if) this communication from $\mathrm{P} 2 \mathrm{X}_{1} \mathrm{Rs}$ to RyRs influences the contractile behavior of smooth muscle is not clear. The additional increment of $\mathrm{Ca}^{2+}$ may sum with $\mathrm{P} 2 \mathrm{X}_{1} \mathrm{R}$ and VDCC-mediated $\mathrm{Ca}^{2+}$ to augment the transient contraction. Alternatively, CICRactivated RyRs could, in theory, couple to $\mathrm{BK}_{\mathrm{Ca}}$ channels to oppose contraction. Depending on the relative speed of $\mathrm{IP}_{3}$ production by concurrent activation of adrenergic or muscarinic receptors, it is also possible that $\mathrm{Ca}^{2+}$ influx through $\mathrm{P}_{2} \mathrm{X}_{1}$ Rs could amplify local $\mathrm{IP}_{3} \mathrm{R}$ activation by $\mathrm{IP}_{3}$, a possibility that has not yet been explored experimentally.

\section{$\mathrm{Ca}^{2+}$ Sparks}

In cardiac and skeletal muscle, local $\mathrm{Ca}^{2+}$ entry through VDCCs activates proximate RyRs, producing $\mathrm{Ca}^{2+}$ sparks that summate to create a substantial increase in global $\mathrm{Ca}^{2+}$; thus, $\mathrm{Ca}^{2+}$ sparks play a dominant role in contraction in these tissues. In smooth muscle, the molecular architecture is much different, resulting in unique linkages that create a phenotypically opposite functional outcome. In particular, the close physical coupling between VDCCs and RyRs that characterizes striated muscle cells is absent in smooth muscle cells. In its place is a close linkage between the RyR and plasma membrane $\mathrm{BK}_{\mathrm{Ca}}$ channels, which are not expressed in cardiac or skeletal muscle cells. As a result of this unique architecture, $\mathrm{Ca}^{2+}$ released by RyRs in the SR in the form of sparks activates juxtaposed $\mathrm{BK}_{\mathrm{Ca}}$ channels, promoting an outward $\mathrm{K}^{+}$current that hyperpolarizes the smooth muscle membrane and reduces VDCC activity. The resulting decrease in $\mathrm{Ca}^{2+}$ influx thus opposes VDCC-mediated smooth muscle contraction (Nelson et al. 1995; Perez et al. 1999; Jaggar et al. 2000). Under this scenario, $\mathrm{Ca}^{2+}$ influx through VDCCs initiates the $\mathrm{BK}_{\mathrm{Ca}}$ channel-mediated feedback mechanism by enhancing RyR activity, by increasing global $\mathrm{Ca}^{2+}$ and $\mathrm{SR} \mathrm{Ca}{ }^{2+}$ stores (Collier et al. 2000; Herrera and Nelson 2002; Wellman and Nelson 2003; Essin and Gollasch 2009).

As is observed with $\mathrm{P}_{2} \mathrm{X}_{1}$ agonists, simultaneous activation of RyRs by rapid addition of high levels of the RyR activator, caffeine, can cause global $\mathrm{Ca}^{2+}$ transients and a transient contraction (Wellman and Nelson 2003). 
$\mathrm{Ca}^{2+}$ Waves

$\mathrm{Ca}^{2+}$ waves normally occur asynchronously in smooth muscle cells. However, in some vascular beds, $\mathrm{Ca}^{2+}$ waves may synchronize in neighboring arterial myocytes to initiate vasomotion (Peng et al. 2001), supporting the idea that $\mathrm{Ca}^{2+}$ waves can supply the $\mathrm{Ca}^{2+}$ needed for smooth muscle contraction (Kasai et al. 1997; Boittin et al. 1999; Mufti et al. 2010). Alternatively, $\mathrm{Ca}^{2+}$ waves can influence contractility indirectly through activation of $\mathrm{Ca}^{2+}$-dependent ion channels located in the plasmalemmal membrane. For example, $\mathrm{Ca}^{2+}$ waves can activate $\mathrm{Cl}_{\mathrm{Ca}}$ channels to promote membrane depolarization leading to enhanced $\mathrm{Ca}^{2+}$ entry through VDCCs (Mironneau et al. 1996). $\mathrm{Ca}^{2+}$ waves can also activate $\mathrm{BK}_{\mathrm{Ca}}$ channels, thereby promoting membrane potential hyperpolarization, closure of VDCCs, and induction of smooth muscle relaxation (Young et al. 2001). Thus, while information on $\mathrm{Ca}^{2+}$ waves in smooth muscle continues to accumulate, the physiological function of these $\mathrm{Ca}^{2+}$ signals remains uncertain.

\section{$\mathrm{Ca}^{2+}$-DEPENDENT TRANSCRIPTION FACTOR ACTIVATION}

\section{Global $\mathrm{Ca}^{2+}$ : Excitation-Transcription Coupling}

Excitation-contraction coupling, in which depolarization induces contraction through VDCC-mediated increases in intracellular $\mathrm{Ca}^{2+}$, is paralleled by a conceptually similar mechanism that links depolarization-induced increases in $\left[\mathrm{Ca}^{2+}\right]_{\mathrm{i}}$ to activation of $\mathrm{Ca}^{2+}$ sensitive transcription factors. This process, which has been termed excitation-transcription coupling, translates short-term $\mathrm{Ca}^{2+}$-signaling and contractile events into long-term regulation of the smooth muscle cell transcriptome. Unlike cardiac and skeletal muscle cells, smooth muscle cells are highly plastic; their phenotype is maintained through dynamic regulation of gene expression in response to environmental cues (Owens 1995). Thus, excitation-transcription coupling serves to maintain the contractile phenotype by promoting the expression of smooth muscle-specific genes. It also provides a mechanism for phenotypic switching to a "synthetic" phenotype characterized by expression of genes that promote proliferation, matrix deposition, and other functions that come into play under pathological conditions and in the context of vessel repair and new vessel formation. Recent work from Owens and colleagues (Wamhoff et al. 2004) has shown that VDCCmediated elevations in $\mathrm{Ca}^{2+}$ act through two distinct mechanisms to regulate the contractile and synthetic/proliferative phenotypes. In the first, depolarization-induced $\mathrm{Ca}^{2+}$ elevation induces SRF (serum response factor)-regulated smooth muscle-specific genes (e.g., myosin heavy chain, smooth muscle $\alpha$-actin) through activation of Rho/Rho kinase and stimulation of myocardin, a potent coactivator of SRF first identified by Olson and colleagues (Wang et al. 2001a). In the second mechanism, elevated intracellular $\mathrm{Ca}^{2+}$ acts through calmodulin-dependent kinase (CaMK) to activate CREB (cAMP responsive element binding protein) and the immediately early gene, $\mathrm{c}$-fos, which is involved in proliferative responses. A similar CaMK/ CREB-dependent mechanism has been implicated in the VDCC-mediated induction of Egr-1 (Pulver-Kaste et al. 2006) and c-fos (Cartin et al. 2000) in native cerebral arteries, and TRP channels in gall bladder smooth muscle (Morales et al. 2007). In this latter study, a role for the phosphatase calcineurin was also suggested.

\section{Spatially and Temporally Modulated} $\mathrm{Ca}^{2+}$ Signals

Studies on the effects of $\mathrm{Ca}^{2+}$ signal modulation on transcription factor activation in smooth muscle cells are limited, but seminal work by Lewis and Tsien and colleagues (Dolmetsch et al. 1998; Li et al. 1998) in nonexcitable cells has shown a role for amplitude and frequency modulation of $\mathrm{Ca}^{2+}$ signals in differentially regulating the activity of $\mathrm{Ca}^{2+}$-sensitive transcription factors. These researchers showed that large transient increases in $\left[\mathrm{Ca}^{2+}\right]_{\mathrm{i}}$ are sufficient to robustly activate NF- $\kappa \mathrm{B}$ and c-Jun terminal kinase (JNK) but not NFAT (nuclear factor of activated T-cells), which is effectively activated by a sustained, graded increase in 
D.C. Hill-Eubanks et al.

global intracellular $\mathrm{Ca}^{2+}$. It has been further shown that activation of $\mathrm{Ca}^{2+}$-sensitive transcription factors is modulated by oscillatory elevations in intracellular $\mathrm{Ca}^{2+}$ : for all transcription factors tested (NFAT, Oct/OAP, and NF- $\kappa \mathrm{B}$ ), high-frequency oscillations enhanced the efficacy of a given increase in $\mathrm{Ca}^{2+}$, whereas lowfrequency oscillations activated only NF- $\kappa$ B.

\section{$\mathrm{Ca}^{2+}$-Signaling Microdomains}

Recent studies by Santana and coworkers suggest a model in which the scaffolding protein AKAP250 targets PKC and calcineurin to caveolin-containing membrane microdomains, where they associated with VDCCs to form a signaling unit capable of mediating persistent $\mathrm{Ca}^{2+}$ sparklets (Santana and Navedo 2009). These studies further indicate that persistent VDCC-mediated $\mathrm{Ca}^{2+}$ sparklets activate the $\mathrm{Ca}^{2+}$-calmodulin-dependent transcription factor NFATc3 (Nieves-Cintron et al. 2008), which modulates expression of the Kv2.1 voltagedependent $\mathrm{K}^{+}$channel and the $\beta 1$ subunit of the $\mathrm{BK}_{\mathrm{Ca}}$ channel in these cells (Amberg et al. 2004). By extension, similar complexes of P2 $\mathrm{X}_{1}$ Rs with kinases and phosphatases might form $\mathrm{Ca}^{2+}$-signaling microdomains in postjunctional smooth muscle cell membranes, enabling nerve-evoked purinergic transients to regulate activation of NFAT or other $\mathrm{Ca}^{2+}$ sensitive transcription factors.

\section{CONCLUSIONS}

In addition to global elevations in intracellular $\mathrm{Ca}^{2+}$ mediated by VDCCs, smooth muscle shows a variety of local $\mathrm{Ca}^{2+}$ signals, including $\mathrm{Ca}^{2+}$ sparks (RyRs), $\mathrm{Ca}^{2+}$ puffs ( $\mathrm{IP}_{3} \mathrm{Rs}^{2+}, \mathrm{Ca}^{2+}$ waves ( $\left.\mathrm{IP}_{3} \mathrm{Rs} / \mathrm{RyRs}\right)$, junctional $\mathrm{Ca}^{2+}$ transients $\left(\mathrm{P}_{2} \mathrm{X}_{1} \mathrm{Rs}\right), \mathrm{Ca}^{2+}$ flashes (VDCCs), and $\mathrm{Ca}^{2+}$ sparklets (VDCCs). Each signal represents the manifestation of different molecular circuits, which collectively serve to modulate membrane potential, contractility, and gene expression.

\section{ACKNOWLEDGMENTS}

The work was supported by NIH grants R37DK 053832, RO1 DK065947, RO1 HL44455, PO1 HL077378, P20 R016435, and RO1 HL098243; the Totman Trust for Medical Research; Research into Ageing (P332); The Royal Society (RG080197); and the British Heart Foundation (PG/07/115).

\section{REFERENCES}

Amberg GC, Rossow CF, Navedo MF, Santana LF. 2004. NFATc3 regulates Kv2.1 expression in arterial smooth muscle. J Biol Chem 279: 47326-47334.

Angelotti T, Hofmann F. 1996. Tissue-specific expression of splice variants of the mouse voltage-gated calcium channel $\alpha 2 \delta$ subunit. FEBS Lett 397: 331-337.

Aschrafi A, Sadtler S, Niculescu C, Rettinger J, Schmalzing G. 2004. Trimeric architecture of homomeric P2X2 and heteromeric P2X1+2 receptor subtypes. J Mol Biol 342: $333-343$.

Bayguinov O, Hagen B, Bonev AD, Nelson MT, Sanders KM. 2000. Intracellular calcium events activated by ATP in murine colonic myocytes. Am J Physiol Cell Physiol 279: C126-C135.

Benham CD, Bolton TB. 1986. Spontaneous transient outward currents in single visceral and vascular smooth muscle cells of the rabbit. J Physiol 381: 385-406.

Benham CD, Tsien RW. 1987. A novel receptor-operated $\mathrm{Ca}^{2+}$-permeable channel activated by ATP in smooth muscle. Nature 328: 275-278.

Berridge MJ. 1997. Elementary and global aspects of calcium signalling. J Physiol 499: 291-306.

Bielefeldt K. 1999. Molecular diversity of voltage-sensitive calcium channels in smooth muscle cells. J Lab Clin Med 133: 469-477.

Birnbaumer L, Qin N, Olcese R, Tareilus E, Platano D, Costantin J, Stefani E. 1998. Structures and functions of calcium channel $\beta$ subunits. J Bioenerg Biomembr 30: 357-375.

Boittin FX, Macrez N, Halet G, Mironneau J. 1999. Norepinephrine-induced $\mathrm{Ca}^{2+}$ waves depend on $\operatorname{InsP}(3)$ and ryanodine receptor activation in vascular myocytes. $A m$ J Physiol 277: C139-C151.

Boittin FX, Coussin F, Morel JL, Halet G, Macrez N, Mironneau J. 2000. $\mathrm{Ca}^{2+}$ signals mediated by $\operatorname{Ins}(1,4,5) \mathrm{P}(3)$ gated channels in rat ureteric myocytes. Biochem J 349: 323-332.

Bonev AD, Jaggar JH, Rubart M, Nelson MT. 1997. Activators of protein kinase $\mathrm{C}$ decrease $\mathrm{Ca}^{2+}$ spark frequency in smooth muscle cells from cerebral arteries. Am J Physiol 273: C2090-C2095.

Bootman MD, Berridge MJ. 1996. Subcellular $\mathrm{Ca}^{2+}$ signals underlying waves and graded responses in HeLa cells. Curr Biol 6: 855-865.

Bradley JE, Anderson UA, Woolsey SM, Thornbury KD, McHale NG, Hollywood MA. 2004. Characterization of T-type calcium current and its contribution to electrical activity in rabbit urethra. Am J Physiol Cell Physiol 286: C1078-C1088.

Brain KL, Jackson VM, Trout SJ, Cunnane TC. 2002. Intermittent ATP release from nerve terminals elicits focal smooth muscle $\mathrm{Ca}^{2+}$ transients in mouse vas deferens. J Physiol 541: 849-862. 
Brain KL, Cuprian AM, Williams DJ, Cunnane TC. 2003. The sources and sequestration of $\mathrm{Ca}^{2+}$ contributing to neuroeffector $\mathrm{Ca}^{2+}$ transients in the mouse vas deferens. J Physiol 553: 627-635.

Burdyga T, Wray S. 2005. Action potential refractory period in ureter smooth muscle is set by Ca sparks and BK channels. Nature 436: 559-562.

Cannell MB, Cheng H, Lederer WJ. 1995. The control of calcium release in heart muscle. Science 268: 1045-1049.

Cartin L, Lounsbury KM, Nelson MT. 2000. Coupling of $\mathrm{Ca}^{2+}$ to CREB activation and gene expression in intact cerebral arteries from mouse: Roles of ryanodine receptors and voltage-dependent $\mathrm{Ca}^{2+}$ channels. Circ Res 86: $760-767$.

Catterall WA. 2000. Structure and regulation of voltagegated $\mathrm{Ca}^{2+}$ channels. Annu Rev Cell Dev Biol 16: 521555.

Cheng H, Lederer WJ. 2008. Calcium sparks. Physiol Rev 88: 1491-1545.

Cheng H, Lederer WJ, Cannell MB. 1993. Calcium sparks: Elementary events underlying excitation-contraction coupling in heart muscle. Science 262: 740-744.

Collier ML, Ji G, Wang Y, Kotlikoff MI. 2000. Calciuminduced calcium release in smooth muscle: Loose coupling between the action potential and calcium release. J Gen Physiol 115: 653-662.

Curtis BM, Catterall WA. 1984. Purification of the calcium antagonist receptor of the voltage-sensitive calcium channel from skeletal muscle transverse tubules. Biochemistry 23: 2113-2118.

Demuro A, Parker I. 2004. Imaging the activity and localization of single voltage-gated $\mathrm{Ca}^{2+}$ channels by total internal reflection fluorescence microscopy. Biophys $J$ 86: 3250-3259.

Dolmetsch RE, Xu K, Lewis RS. 1998. Calcium oscillations increase the efficiency and specificity of gene expression [see comments]. Nature 392: 933-936.

Essin K, Gollasch M. 2009. Role of ryanodine receptor subtypes in initiation and formation of calcium sparks in arterial smooth muscle: Comparison with striated muscle. J Biomed Biotechnol 2009: 135249.

Feske S, Gwack Y, Prakriya M, Srikanth S, Puppel SH, Tanasa B, Hogan PG, Lewis RS, Daly M, Rao A. 2006. A mutation in Orail causes immune deficiency by abrogating CRAC channel function. Nature 441: 179-185.

Foskett JK, White C, Cheung KH, Mak DO. 2007. Inositol trisphosphate receptor $\mathrm{Ca}^{2+}$ release channels. Physiol Rev 87: 593-658.

Giachini FR, Chiao CW, Carneiro FS, Lima VV, Carneiro ZN, Dorrance AM, Tostes RC, Webb RC. 2009. Increased activation of stromal interaction molecule-1/Orai-1 in aorta from hypertensive rats: A novel insight into vascular dysfunction. Hypertension 53: 409-416.

Giachini FR, Webb RC, Tostes RC. 2010. STIM and Orai proteins: Players in sexual differences in hypertensionassociated vascular dysfunction? Clin Sci (Lond) 118: 391-396.

Gordienko DV, Bolton TB. 2002. Crosstalk between ryanodine receptors and $\operatorname{IP}(3)$ receptors as a factor shaping spontaneous $\mathrm{Ca}^{2+}$-release events in rabbit portal vein myocytes. J Physiol 542: 743-762.
Gordienko DV, Bolton TB, Cannell MB. 1998. Variability in spontaneous subcellular calcium release in guinea-pig ileum smooth muscle cells. J Physiol 507: 707-720.

Grayson TH, Haddock RE, Murray TP, Wojcikiewicz RJ, Hill CE. 2004. Inositol 1,4,5-trisphosphate receptor subtypes are differentially distributed between smooth muscle and endothelial layers of rat arteries. Cell Calcium 36: 447-458.

Heppner TJ, Bonev AD, Santana LF, Nelson MT. 2002. Alkaline pH shifts $\mathrm{Ca}^{2+}$ sparks to $\mathrm{Ca}^{2+}$ waves in smooth muscle cells of pressurized cerebral arteries. Am J Physiol Heart Circ Physiol 283: H2169-H2176.

Heppner TJ, Bonev AD, Nelson MT. 2005. Elementary purinergic $\mathrm{Ca}^{2+}$ transients evoked by nerve stimulation in rat urinary bladder smooth muscle. J Physiol 564: 201-212.

Heppner TJ, Werner ME, Nausch B, Vial C, Evans RJ, Nelson MT. 2009. Nerve-evoked purinergic signalling suppresses action potentials, $\mathrm{Ca}^{2+}$ flashes and contractility evoked by muscarinic receptor activation in mouse urinary bladder smooth muscle. J Physiol 587: 5275-5288.

Herrera GM, Heppner TJ, Nelson MT. 2001. Voltage dependence of the coupling of $\mathrm{Ca}^{2+}$ sparks to $\mathrm{BK}(\mathrm{Ca})$ channels in urinary bladder smooth muscle. Am J Physiol Cell Physiol 280: C481-C490.

Herrera GM, Nelson MT. 2002. Differential regulation of SK and $\mathrm{BK}$ channels by $\mathrm{Ca}^{2+}$ signals from $\mathrm{Ca}^{2+}$ channels and ryanodine receptors in guinea-pig urinary bladder myocytes. J Physiol 541: 483-492.

Hill-Eubanks DC, Werner ME, Nelson MT. 2010. Local elementary purinergic-induced $\mathrm{Ca}^{2+}$ transients: From optical mapping of nerve activity to local $\mathrm{Ca}^{2+}$ signaling networks. J Gen Physiol 136: 149-154.

Hirose K, Kadowaki S, Tanabe M, Takeshima H, Iino M. 1999. Spatiotemporal dynamics of inositol 1,4,5-trisphosphate that underlies complex $\mathrm{Ca}^{2+}$ mobilization patterns. Science 284: 1527-1530.

Hogg RC, Wang Q, Helliwell RM, Large WA. 1993. Properties of spontaneous inward currents in rabbit pulmonary artery smooth muscle cells. Pflugers Arch 425: 233-240.

Hosey MM, Barhanin J, Schmid A, Vandaele S, Ptasienski J, O'Callahan C, Cooper C, Lazdunski M. 1987. Photoaffinity labelling and phosphorylation of a 165 kilodalton peptide associated with dihydropyridine and phenylalkylamine-sensitive calcium channels. Biochem Biophys Res Commun 147: 1137-1145.

Hullin R, Singer-Lahat D, Freichel M, Biel M, Dascal N, Hofmann F, Flockerzi V. 1992. Calcium channel $\beta$ subunit heterogeneity: Functional expression of cloned cDNA from heart, aorta and brain. $Е M B O J$ 11: 885-890.

Iino M, Kasai H, Yamazawa T. 1994. Visualization of neural control of intracellular $\mathrm{Ca}^{2+}$ concentration in single vascular smooth muscle cells in situ. EMBO $J$ 13: 5026-5031.

Jaggar JH, Nelson MT. 2000. Differential regulation of $\mathrm{Ca}^{2+}$ sparks and $\mathrm{Ca}^{2+}$ waves by UTP in rat cerebral artery smooth muscle cells. Am J Physiol Cell Physiol 279: C1528-C1539.

Jaggar JH, Stevenson AS, Nelson MT. 1998a. Voltage dependence of $\mathrm{Ca}^{2+}$ sparks in intact cerebral arteries. Am J Physiol 274: C1755-C1761. 
D.C. Hill-Eubanks et al.

Jaggar JH, Wellman GC, Heppner TJ, Porter VA, Perez GJ, Gollasch M, Kleppisch T, Rubart M, Stevenson AS, Lederer WJ, et al. 1998b. $\mathrm{Ca}^{2+}$ channels, ryanodine receptors and $\mathrm{Ca}^{2+}$-activated $\mathrm{K}^{+}$channels: A functional unit for regulating arterial tone. Acta Physiol Scand 164: $577-587$.

Jaggar JH, Porter VA, Lederer WJ, Nelson MT. 2000. Calcium sparks in smooth muscle. Am J Physiol Cell Physiol 278: C235-C256.

Jurkat-Rott K, Lehmann-Horn F. 2004. The impact of splice isoforms on voltage-gated calcium channel $\alpha 1$ subunits. J Physiol 554: 609-619.

Kasai Y, Yamazawa T, Sakurai T, Taketani Y, Iino M. 1997. Endothelium-dependent frequency modulation of $\mathrm{Ca}^{2+}$ signalling in individual vascular smooth muscle cells of the rat. J Physiol 504: 349-357.

Keef KD, Hume JR, Zhong J. 2001. Regulation of cardiac and smooth muscle $\mathrm{Ca}^{2+}$ channels $\left(\mathrm{Ca}_{\mathrm{V}} 1.2 \mathrm{a}, \mathrm{b}\right)$ by protein kinases. Am J Physiol Cell Physiol 281: C1743-C1756.

Khakh BS. 2001. Molecular physiology of P2X receptors and ATP signalling at synapses. Nat Rev Neurosci 2: 165-174.

Klein MG, Cheng H, Santana LF, Jiang YH, Lederer WJ, Schneider MF. 1996. Two mechanisms of quantized calcium release in skeletal muscle. Nature 379: 455-458.

Klockner U, Isenberg G. 1985. Action potentials and net membrane currents of isolated smooth muscle cells (urinary bladder of the guinea-pig). Pflugers Arch 405: 329-339.

Knot HJ, Nelson MT. 1998. Regulation of arterial diameter and wall $\left[\mathrm{Ca}^{2+}\right]$ in cerebral arteries of rat by membrane potential and intravascular pressure. J Physiol 508: 199-209.

Kuo IY, Wolfle SE, Hill CE. 2010. T-type calcium channels and vascular function: The new kid on the block? J Physiol 589: 783-795.

Lamont C, Wier WG. 2002. Evoked and spontaneous purinergic junctional $\mathrm{Ca}^{2+}$ transients (jCaTs) in rat small arteries. Circ Res 91: 454-456.

Lamont C, Vial C, Evans RJ, Wier WG. 2006. P2X1 receptors mediate sympathetic postjunctional $\mathrm{Ca}^{2+}$ transients in mesenteric small arteries. Am J Physiol Heart Circ Physiol 291: H3106-3113.

Lanner JT, Georgiou DK, Joshi AD, Hamilton SL. 2010. Ryanodine receptors: Structure, expression, molecular details, and function in calcium release. Cold Spring Harb Perspect Biol 2: a003996.

Lee CH, Poburko D, Kuo KH, Seow CY, van Breemen C. 2002. $\mathrm{Ca}^{2+}$ oscillations, gradients, and homeostasis in vascular smooth muscle. Am J Physiol Heart Circ Physiol 282: H1571-H1583.

Leung AT, Imagawa T, Campbell KP. 1987. Structural characterization of the 1,4-dihydropyridine receptor of the voltage-dependent $\mathrm{Ca}^{2+}$ channel from rabbit skeletal muscle. Evidence for two distinct high molecular weight subunits. J Biol Chem 262: 7943-7946.

Li W, Llopis J, Whitney M, Zlokarnik G, Tsien RY. 1998. Cellpermeant caged InsP3 ester shows that $\mathrm{Ca}^{2+}$ spike frequency can optimize gene expression [see comments]. Nature 392: 936-941.

Liou J, Kim ML, Heo WD, Jones JT, Myers JW, Ferrell JE Jr, Meyer T. 2005. STIM is a $\mathrm{Ca}^{2+}$ sensor essential for
$\mathrm{Ca}^{2+}$-store-depletion-triggered $\mathrm{Ca}^{2+}$ influx. Curr Biol 15: $1235-1241$.

Lopez-Lopez JR, Shacklock PS, Balke CW, Wier WG. 1995. Local calcium transients triggered by single L-type calcium channel currents in cardiac cells. Science 268: 1042-1045.

Maravall M, Mainen ZF, Sabatini BL, Svoboda K. 2000. Estimating intracellular calcium concentrations and buffering without wavelength ratioing. Biophys $J$ 78: 2655-2667.

Miriel VA, Mauban JR, Blaustein MP, Wier WG. 1999. Local and cellular $\mathrm{Ca}^{2+}$ transients in smooth muscle of pressurized rat resistance arteries during myogenic and agonist stimulation. J Physiol 518 (Pt 3): 815-824.

Mironneau J, Arnaudeau S, Macrez-Lepretre N, Boittin FX. 1996. $\mathrm{Ca}^{2+}$ sparks and $\mathrm{Ca}^{2+}$ waves activate different $\mathrm{Ca}^{2+}$-dependent ion channels in single myocytes from rat portal vein. Cell Calcium 20: 153-160.

Mizuno Y, Isotani E, Huang J, Ding H, Stull JT, Kamm KE. 2008. Myosin light chain kinase activation and calcium sensitization in smooth muscle in vivo. Am J Physiol Cell Physiol 295: C358-C364.

Moosmang S, Schulla V, Welling A, Feil R, Feil S, Wegener JW, Hofmann F, Klugbauer N. 2003. Dominant role of smooth muscle L-type calcium channel $\mathrm{Ca}_{\mathrm{v}} 1.2$ for blood pressure regulation. EMBO J 22: 6027-6034.

Morales S, Diez A, Puyet A, Camello PJ, Camello-Almaraz C, Bautista JM, Pozo MJ. 2007. Calcium controls smooth muscle TRPC gene transcription via the CaMK/ calcineurin-dependent pathways. Am J Physiol Cell Physiol 292: C553-C563.

Mufti RE, Brett SE, Tran CH, Abd El-Rahman R, Anfinogenova Y, El-Yazbi A, Cole WC, Jones PP, Chen SR, Welsh DG. 2010. Intravascular pressure augments cerebral arterial constriction by inducing voltage-insensitive $\mathrm{Ca}^{2+}$ waves. J Physiol 588: 3983-4005.

Mulryan K, Gitterman DP, Lewis CJ, Vial C, Leckie BJ, Cobb AL, Brown JE, Conley EC, Buell G, Pritchard CA, et al. 2000. Reduced vas deferens contraction and male infertility in mice lacking P2X1 receptors. Nature 403: 86-89.

Murakami M, Yamamura H, Suzuki T, Kang MG, Ohya S, Murakami A, Miyoshi I, Sasano H, Muraki K, Hano T, et al. 2003. Modified cardiovascular L-type channels in mice lacking the voltage-dependent $\mathrm{Ca}^{2+}$ channel $\beta 3$ subunit. J Biol Chem 278: 43261-43267.

Navedo MF, Amberg GC, Votaw VS, Santana LF. 2005. Constitutively active L-type $\mathrm{Ca}^{2+}$ channels. Proc Natl Acad Sci 102: 11112-11117.

Nelson MT, Patlak JB, Worley JF, Standen NB. 1990. Calcium channels, potassium channels, and voltage dependence of arterial smooth muscle tone. Am J Physiol 259: C3-C18.

Nelson MT, Cheng H, Rubart M, Santana LF, Bonev AD, Knot HJ, Lederer WJ. 1995. Relaxation of arterial smooth muscle by calcium sparks [see comments]. Science 270: 633-637.

Newton CL, Mignery GA, Sudhof TC. 1994. Co-expression in vertebrate tissues and cell lines of multiple inositol 1,4,5-trisphosphate (InsP3) receptors with distinct affinities for InsP3. J Biol Chem 269: 28613-28619. 
Neylon CB, Richards SM, Larsen MA, Agrotis A, Bobik A. 1995. Multiple types of ryanodine receptor $/ \mathrm{Ca}^{2+}$ release channels are expressed in vascular smooth muscle. Biochem Biophys Res Commun 215: 814-821.

Ng LC, Ramduny D, Airey JA, Singer CA, Keller PS, Shen XM, Tian H, Valencik M, Hume JR. 2010. Orail interacts with STIM1 and mediates capacitative $\mathrm{Ca}^{2+}$ entry in mouse pulmonary arterial smooth muscle cells. Am J Physiol Cell Physiol 299: C1079-C1090.

Nieves-Cintron M, Amberg GC, Navedo MF, Molkentin JD, Santana LF. 2008. The control of $\mathrm{Ca}^{2+}$ influx and NFATc3 signaling in arterial smooth muscle during hypertension. Proc Natl Acad Sci 105: 15623-15628.

Nikitina E, Zhang ZD, Kawashima A, Jahromi BS, Bouryi VA, Takahashi M, Xie A, Macdonald RL. 2007. Voltage-dependent calcium channels of dog basilar artery. J Physiol 580: 523-541.

North RA. 2002. Molecular physiology of P2X receptors. Physiol Rev 82: 1013-1067.

Owens GK. 1995. Regulation of differentiation of vascular smooth muscle cells. Physiol Rev 75: 487-517.

Park Hopson K, Truelove J, Chun J, Wang Y, Waeber C. 2011 S1P activates Store-operated calcium entry via receptor and non receptor-mediated pathways in vascular smooth muscle cells. Am J Physiol Cell Physiol 300: 919-926.

Peel SE, Liu B, Hall IP. 2006. A key role for STIM1 in store operated calcium channel activation in airway smooth muscle. Respir Res 7: 119.

Peel SE, Liu B, Hall IP. 2008. ORAI and store-operated calcium influx in human airway smooth muscle cells. Am J Respir Cell Mol Biol 38: 744-749.

Peng H, Matchkov V, Ivarsen A, Aalkjaer C, Nilsson H. 2001. Hypothesis for the initiation of vasomotion. Circ Res 88: 810-815.

Perez GJ, Bonev AD, Patlak JB, Nelson MT. 1999. Functional coupling of ryanodine receptors to $\mathrm{KCa}$ channels in smooth muscle cells from rat cerebral arteries. J Gen Physiol 113: 229-238.

Perez GJ, Bonev AD, Nelson MT. 2001. Micromolar $\mathrm{Ca}^{2+}$ from sparks activates $\mathrm{Ca}^{2+}$-sensitive $\mathrm{K}^{+}$channels in rat cerebral artery smooth muscle. Am J Physiol Cell Physiol 281: C1769-C1775.

Perez-Reyes E. 2003. Molecular physiology of low-voltage-activated t-type calcium channels. Physiol Rev 83: $117-161$.

Pozo MJ, Perez GJ, Nelson MT, Mawe GM. 2002. $\mathrm{Ca}^{2+}$ sparks and BK currents in gallbladder myocytes: Role in CCK-induced response. Am J Physiol Gastrointest Liver Physiol 282: G165-G174.

Pozzan T, Rizzuto R, Volpe P, Meldolesi J. 1994. Molecular and cellular physiology of intracellular calcium stores. Physiol Rev 74: 595-636.

Prinz G, Diener M. 2008. Characterization of ryanodine receptors in rat colonic epithelium. Acta Physiol (Oxf) 193: $151-162$.

Pulver-Kaste RA, Barlow CA, Bond J, Watson A, Penar PL, Tranmer B, Lounsbury KM. 2006. $\mathrm{Ca}^{2+}$ sourcedependent transcription of CRE-containing genes in vascular smooth muscle. Am J Physiol Heart Circ Physiol 291: 97-105.
Reuter H. 1983. Calcium channel modulation by neurotransmitters, enzymes and drugs. Nature 301: 569-574.

Roos J, DiGregorio PJ, Yeromin AV, Ohlsen K, Lioudyno M, Zhang S, Safrina O, Kozak JA, Wagner SL, Cahalan MD, et al. 2005. STIM1, an essential and conserved component of store-operated $\mathrm{Ca}^{2+}$ channel function. $J$ Cell Biol 169: 435-445.

Ruehlmann DO, Lee CH, Poburko D, van Breemen C. 2000. Asynchronous $\mathrm{Ca}^{2+}$ waves in intact venous smooth muscle. Circ Res 86: E72-E79.

Sanders KM. 2001. Invited review: Mechanisms of calcium handling in smooth muscles. J Appl Physiol 91: 14381449.

Santana LF, Navedo MF. 2009. Molecular and biophysical mechanisms of $\mathrm{Ca}^{2+}$ sparklets in smooth muscle. J Mol Cell Cardiol 47: 436-444.

Santana LF, Navedo MF, Amberg GC, Nieves-Cintron M, Votaw VS, Ufret-Vincenty CA. 2008. Calcium sparklets in arterial smooth muscle. Clin Exp Pharmacol Physiol 35: 1121-1126.

Schneider P, Hopp HH, Isenberg G. 1991. $\mathrm{Ca}^{2+}$ influx through ATP-gated channels increments $\left[\mathrm{Ca}^{2+}\right]_{\mathrm{i}}$ and inactivates ICa in myocytes from guinea-pig urinary bladder. J Physiol 440: 479-496.

Sieck GC, Kannan MS, Prakash YS. 1997. Heterogeneity in dynamic regulation of intracellular calcium in airway smooth muscle cells. Can J Physiol Pharmacol 75: 878888.

Snutch TP, Sutton KG, Zamponi GW. 2001. Voltagedependent calcium channels-Beyond dihydropyridine antagonists. Curr Opin Pharmacol 1: 11-16.

Somlyo AP, Somlyo AV. 2003. $\mathrm{Ca}^{2+}$ sensitivity of smooth muscle and nonmuscle myosin II: Modulated by G proteins, kinases, and myosin phosphatase. Physiol Rev 83: $1325-1358$.

Stevens RJ, Weinert JS, Publicover NG. 1999. Visualization of origins and propagation of excitation in canine gastric smooth muscle. Am J Physiol 277: C448-C460.

Stull JT, Lin PJ, Krueger JK, Trewhella J, Zhi G. 1998. Myosin light chain kinase: Functional domains and structural motifs. Acta Physiol Scand 164: 471-482.

Takahashi Y, Watanabe H, Murakami M, Ono K, Munehisa Y, Koyama T, Nobori K, Iijima T, Ito H. 2007. Functional role of stromal interaction molecule 1 (STIM1) in vascular smooth muscle cells. Biochem Biophys Res Commun 361: 934-940.

Tasker PN, Michelangeli F, Nixon GF. 1999. Expression and distribution of the type 1 and type 3 inositol 1,4, 5trisphosphate receptor in developing vascular smooth muscle. Circ Res 84: 536-542.

Thomas D, Lipp P, Berridge MJ, Bootman MD. 1998. Hormone-evoked elementary $\mathrm{Ca}^{2+}$ signals are not stereotypic, but reflect activation of different size channel clusters and variable recruitment of channels within a cluster. J Biol Chem 273: 27130-27136.

Tsien RY. 1980. New calcium indicators and buffers with high selectivity against magnesium and protons: Design, synthesis, and properties of prototype structures. Biochemistry 19: 2396-2404. 
D.C. Hill-Eubanks et al.

Vaghy PL, Williams JS, Schwartz A. 1987. Receptor pharmacology of calcium entry blocking agents. Am J Cardiol 59: $9 \mathrm{~A}-17 \mathrm{~A}$.

Vaithianathan T, Narayanan D, Asuncion-Chin MT, Jeyakumar LH, Liu J, Fleischer S, Jaggar JH, Dopico AM. 2010 Subtype identification and functional characterization of ryanodine receptors in rat cerebral artery myocytes. $\mathrm{Am} \mathrm{J}$ Physiol Cell Physiol 299: C264-C278.

Varnai P, Hunyady L, Balla T. 2009. STIM and Orai: The long-awaited constituents of store-operated calcium entry. Trends Pharmacol Sci 30: 118-128.

Vial C, Evans RJ. 2002. P2X(1) receptor-deficient mice establish the native $\mathrm{P} 2 \mathrm{X}$ receptor and a P2Y6-like receptor in arteries. Mol Pharmacol 62: 1438-1445.

Vig M, Peinelt C, Beck A, Koomoa DL, Rabah D, KoblanHuberson M, Kraft S, Turner H, Fleig A, Penner R, et al. 2006. CRACM1 is a plasma membrane protein essential for store-operated $\mathrm{Ca}^{2+}$ entry. Science 312: $1220-1223$.

Wamhoff BR, Bowles DK, McDonald OG, Sinha S, Somlyo AP, Somlyo AV, Owens GK. 2004. L-type voltage-gated $\mathrm{Ca}^{2+}$ channels modulate expression of smooth muscle differentiation marker genes via a rho kinase/myocardin/SRF-dependent mechanism. Circ Res 95: 406-414.

Wang D, Chang PS, Wang Z, Sutherland L, Richardson JA, Small E, Krieg PA, Olson EN. 2001a. Activation of cardiac gene expression by myocardin, a transcriptional cofactor for serum response factor. Cell 105: 851-862.

Wang SQ, Song LS, Lakatta EG, Cheng H. 2001b. $\mathrm{Ca}^{2+}$ signalling between single L-type $\mathrm{Ca}^{2+}$ channels and ryanodine receptors in heart cells. Nature 410: 592-596.

Wang Y, Deng X, Hewavitharana T, Soboloff J, Gill DL. 2008. Stim, ORAI and TRPC channels in the control of calcium entry signals in smooth muscle. Clin Exp Pharmacol Physiol 35: 1127-1133.
Wang Y, Deng X, Mancarella S, Hendron E, Eguchi S, Soboloff J, Tang XD, Gill DL. 2010. The calcium store sensor, STIM1, reciprocally controls Orai and $\mathrm{Ca}_{\mathrm{V}} 1.2$ channels. Science 330: 105-109.

Wegener JW, Schulla V, Lee TS, Koller A, Feil S, Feil R, Kleppisch T, Klugbauer N, Moosmang S, Welling A, et al. 2004. An essential role of $\mathrm{Ca}_{\mathrm{v}} 1.2 \mathrm{~L}$-type calcium channel for urinary bladder function. FASEB $J$ 18: 1159-1161.

Wellman GC, Nelson MT. 2003. Signaling between SR and plasmalemma in smooth muscle: Sparks and the activation of $\mathrm{Ca}^{2+}$-sensitive ion channels. Cell Calcium 34: 211-229.

Yang XR, Lin MJ, Yip KP, Jeyakumar LH, Fleischer S, Leung GP, Sham JS. 2005. Multiple ryanodine receptor subtypes and heterogeneous ryanodine receptor-gated $\mathrm{Ca}^{2+}$ stores in pulmonary arterial smooth muscle cells. Am J Physiol Lung Cell Mol Physiol 289: L338-L348.

Young RC, Schumann R, Zhang P. 2001. Intracellular calcium gradients in cultured human uterine smooth muscle: A functionally important subplasmalemmal space. Cell Calcium 29: 183-189.

Zalk R, Lehnart SE, Marks AR. 2007. Modulation of the ryanodine receptor and intracellular calcium. Annu Rev Biochem 76: 367-385.

Zhang SL, Yeromin AV, Zhang XH, Yu Y, Safrina O, Penna A, Roos J, Stauderman KA, Cahalan MD. 2006. Genomewide RNAi screen of $\mathrm{Ca}^{2+}$ influx identifies genes that regulate $\mathrm{Ca}^{2+}$ release-activated $\mathrm{Ca}^{2+}$ channel activity. Proc Natl Acad Sci 103: 9357-9362.

ZhuGe R, Sims SM, Tuft RA, Fogarty KE, Walsh JV Jr. 1998. $\mathrm{Ca}^{2+}$ sparks activate $\mathrm{K}^{+}$and $\mathrm{Cl}^{-}$channels, resulting in spontaneous transient currents in guinea-pig tracheal myocytes. J Physiol 513: 711-718. 


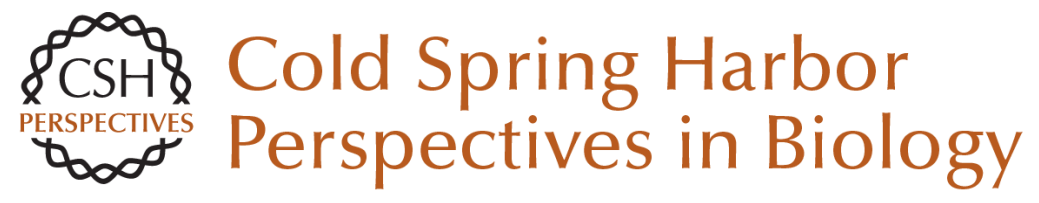

\section{Calcium Signaling in Smooth Muscle}

David C. Hill-Eubanks, Matthias E. Werner, Thomas J. Heppner and Mark T. Nelson

Cold Spring Harb Perspect Biol 2011; doi: 10.1101/cshperspect.a004549 originally published online June 27,2011

\section{Subject Collection Calcium Signaling}

The Endoplasmic Reticulum-Plasma Membrane Junction: A Hub for Agonist Regulation of $\mathrm{Ca}^{2+}$ Entry

Hwei Ling Ong and Indu Suresh Ambudkar

Calcium-Handling Defects and Neurodegenerative Disease

Sean Schrank, Nikki Barrington and Grace E. Stutzmann

Lysosomal $\mathrm{Ca}^{2+}$ Homeostasis and Signaling in Health and Disease

Emyr Lloyd-Evans and Helen Waller-Evans

\section{$\mathrm{Ca}^{2+}$ Signaling in Exocrine Cells}

Malini Ahuja, Woo Young Chung, Wei-Yin Lin, et al.

Functional Consequences of Calcium-Dependent Synapse-to-Nucleus Communication: Focus on Transcription-Dependent Metabolic Plasticity Anna M. Hagenston, Hilmar Bading and Carlos Bas-Orth

Identifying New Substrates and Functions for an Old Enzyme: Calcineurin Jagoree Roy and Martha S. Cyert

Fundamentals of Cellular Calcium Signaling: A Primer

Martin D. Bootman and Geert Bultynck
Primary Active $\mathrm{Ca}^{2+}$ Transport Systems in Health and Disease Jialin Chen, Aljona Sitsel, Veronick Benoy, et al.

Signaling through $\mathrm{Ca}^{2+}$ Microdomains from Store-Operated CRAC Channels Pradeep Barak and Anant B. Parekh

Structural Insights into the Regulation of $\mathrm{Ca}^{2+}$ /Calmodulin-Dependent Protein Kinase II (CaMKII) Moitrayee Bhattacharyya, Deepti Karandur and John Kuriyan

Store-Operated Calcium Channels: From Function to Structure and Back Again Richard S. Lewis

Bcl-2-Protein Family as Modulators of $\mathrm{IP}_{3}$

Receptors and Other Organellar $\mathrm{Ca} 2+$ Channels Hristina Ivanova, Tim Vervliet, Giovanni Monaco, et al.

Calcium Signaling in Cardiomyocyte Function Guillaume Gilbert, Kateryna Demydenko, Eef Dries, et al.

Cytosolic $\mathrm{Ca}^{2+}$ Buffers Are Inherently $\mathrm{Ca}^{2+}$ Signal Modulators Beat Schwaller

For additional articles in this collection, see http://cshperspectives.cshlp.org/cgi/collection/

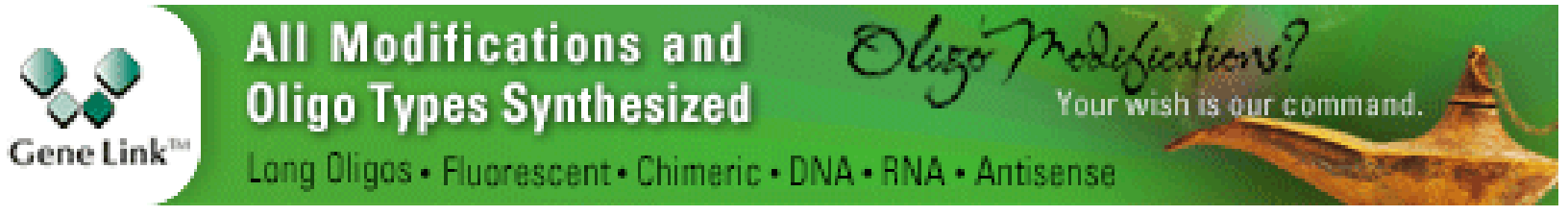


Role of Two-Pore Channels in Embryonic Development and Cellular Differentiation Sarah E. Webb, Jeffrey J. Kelu and Andrew L. Miller

\section{Organellar Calcium Handling in the Cellular \\ Reticular Network}

Wen-An Wang, Luis B. Agellon and Marek Michalak

For additional articles in this collection, see http://cshperspectives.cshlp.org/cgi/collection/

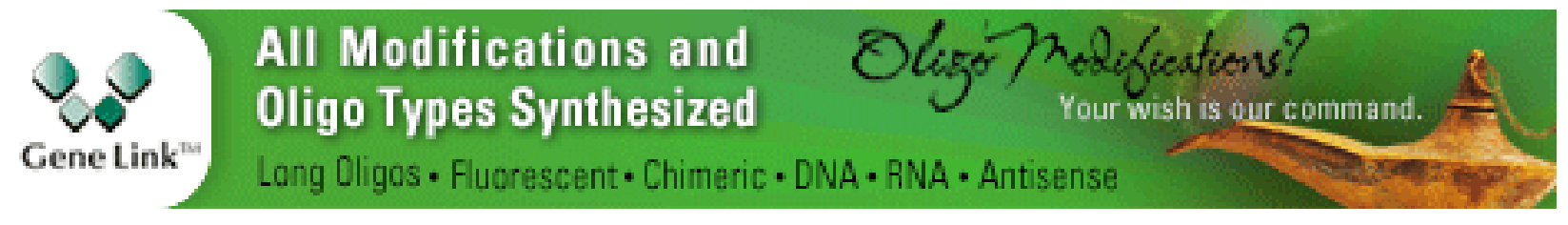

Copyright @ 2011 Cold Spring Harbor Laboratory Press; all rights reserved 